\title{
Equity crowdfunding: First resort or last resort?
}

\author{
XAVIER WALTHOFF-BORM \\ Faculty of Economics and Business Administration \\ Ghent University \\ Sint-Pietersplein 7, 9000 Gent \\ BELGIUM \\ E-mail: Xavier.WalthoffBorm@UGent.be \\ ARMIN SCHWIENBACHER \\ SKEMA Business School-Université Côte d'Azur \\ SKEMA Business School \\ Department of Finance and Accounting \\ Avenue Willy Brandt, 59777 Euralille \\ FRANCE \\ E-mail: armin.schwienbacher@skema.edu
}

TOM VANACKER

Faculty of Economics and Business Administration

Ghent University

Sint-Pietersplein 7, 9000 Gent

BELGIUM

E-mail: TomR.Vanacker@UGent.be

Citation for the published version: Walthoff-Borm, X., Schwienbacher, A., \& Vanacker, T. (2018). Equity crowdfunding: First resort or last resort? Journal of Business Venturing, 33(4), 513-533.

Acknowledgments. We thank the three anonymous $J B V$ reviewers and Jonathan Arthurs for helpful feedback. This paper further benefited from presentations at the 2017 Academy of Management Meeting (Atlanta), the 2nd Entrepreneurial Finance Conference (Gent), the 2016 Babson College Entrepreneurship Research Conference (Nord University Business School), and the 4th Crowdinvesting Symposium (Max Planck Institute for Innovation and Competition, Munich). We acknowledge financial support from the Research Foundation Flanders [Grant \# G012716N]. 


\title{
Equity crowdfunding: First resort or last resort?
}

\begin{abstract}
Prior research has focused on the factors that affect funding success on equity crowdfunding platforms, but a detailed understanding of the factors that drive firms to search for equity crowdfunding in the first place is lacking. Drawing on the pecking order theory, we argue that firms list on equity crowdfunding platforms as a "last resort"- that is, when they lack internal funds and additional debt capacity. In line with the pecking order theory, the empirical evidence shows that firms listed on equity crowdfunding platforms are less profitable, more often have excessive debt levels, and have more intangible assets than matched firms not listed on these platforms. We discuss the implications for theory and practice.
\end{abstract}

Keywords: Entrepreneurial finance, Equity crowdfunding, Financial decision making, Pecking order theory 


\section{Executive Summary}

Equity crowdfunding is an increasingly popular source of external finance for young entrepreneurial firms. In the UK, for instance, an estimated $20 \%$ of all early-stage equity investments occurred through equity crowdfunding platforms in 2015 (Beauhurst, 2015). Extant crowdfunding research has primarily examined the factors that lead to funding success on crowdfunding platforms. In this paper, we examine the factors that drive firms to search for equity crowdfunding (regardless of their ultimate funding success) and thus list on equity crowdfunding platforms.

For this purpose, we draw on the pecking order theory (Myers and Majluf, 1984). In this theory, the costs related to information asymmetry drive entrepreneurs to first employ internal funds whenever available. When internal funds are lacking, entrepreneurs will search for debt financing and choose only external equity financing, including equity crowdfunding, as a last resort. Building on this theoretical perspective, the study advances three hypotheses that operationalize the theory.

The hypotheses are tested using data from 277 firms that searched for equity crowdfunding between 2012 and 2015 on Crowdcube - a leading UK equity crowdfunding platform - and two matched samples of firms that did not list on crowdfunding platforms but were similar in terms of firm industry, age and size. A first matched sample is based on a random set of firms (that do not necessarily have a need for external finance); a second matched sample is based on a set of firms that raised debt (and thus had a demand for external finance).

We find general support for our hypotheses using both samples. Specifically, firms that are more unprofitable and thus lack internal funds are more likely to search for equity crowdfunding. Moreover, firms with excessive debt levels and more intangible assets (i.e., firms 
with limited debt capacity) are also more likely to search for equity crowdfunding. Overall, these findings are consistent with the pecking order theory.

This study contributes to the entrepreneurial finance literature in at least two important ways. First, we add to the crowdfunding literature. Extant crowdfunding research almost exclusively focuses on the subset of firms that were listed on crowdfunding platforms and examines the drivers of funding success on these platforms. We provide first-time evidence on the factors that explain why some firms search for equity crowdfunding while others do not. By doing so, we further address a broader issue in entrepreneurial finance research. Specifically, studies have often focused on firms that raised a particular source of financing but have ignored the firms that searched for and failed to raise that source of financing as well as the firms that did not search for that type of financing (Cumming and Johan, 2017). By investigating firms that searched—successfully or not-for external equity on crowdfunding platforms and matched firms that did not search for funding on these platforms, we thus provide unique insights into the demand for external equity funding and equity crowdfunding in particular.

Second, we examine and extend the boundaries of the pecking order theory with the emergence of equity crowdfunding. While its unique characteristics might enable equity crowdfunding to reverse the pecking order (Bellavitis et al., 2017), in the traditional pecking order theory, equity crowdfunding is just a new source of external equity finance that is used as a last resort. Moreover, studies have had difficulty in disentangling information asymmetry problems (the true driver of financing behavior in the pecking order theory) from entrepreneurs' willingness to retain control, both of which might lead to an observed pecking order (Sapienza et al., 2003). The equity crowdfunding context allows scholars to examine possible pecking order considerations in a context characterized by severe information asymmetry problems (Ahlers et al., 2015) but limited control issues because entrepreneurs generally search for equity 
crowdfunding from a broad pool of small investors and therefore largely retain control over their firms compared with other forms of equity finance.

Finally, the study's findings have important practical implications. Understanding the characteristics of firms that search for equity crowdfunding is instrumental for policy design. The findings also provide new insights into crowd investors, who clearly invest in a risky set of firms. For entrepreneurs that consider searching for equity crowdfunding, the findings suggest that they end up in a pool of firms that try to raise financing as a last resort. Consistent with this idea, we also show that some $40 \%$ of firms that unsuccessfully searched for equity crowdfunding have already failed; this percentage is 2.9 times higher than that for firms that raised equity crowdfunding and 7.2 times higher than that for firms that raised debt. Thus, failure to achieve funding goals during the equity crowdfunding campaign often threatens the very survival of the firm.

\section{Introduction}

For entrepreneurs, internal finance and debt finance are crucial to form and grow a venture (Berger and Udell, 1998; Cassar, 2004; Cosh et al., 2009). External equity finance (e.g., venture capital, angel finance) is usually unavailable (Berger and Udell, 1998) however, or entrepreneurs are unwilling to attract it because of fear of losing their independence (Sapienza et al., 2003). Recently, equity crowdfunding has emerged as a new source of external equity finance that plays an increasingly important role in the financing of young entrepreneurial firms (e.g., Ahlers et al., 2015; Bruton et al., 2015; Cumming and Vismara, 2017; Drover et al., 2017; Short et al., 2017; Vismara, 2016, 2018). This phenomenon provides new opportunities for entrepreneurs, who can now target a broader group of external equity investors. 
Research on equity crowdfunding - "a method of financing, whereby an entrepreneur sells a specified amount of equity or bond-like shares in a company to a group of (small) investors through an open call for funding on Internet-based platforms" (Ahlers et al., 2015: 958) - is developing quickly. Scholars have focused on the success factors in raising equity crowdfunding (e.g., Ahlers et al., 2015; Ralcheva and Roosenboom, 2016; Vismara, 2016). For example, Ahlers et al. (2015) show that retaining equity and providing detailed information about risks make firms more successful on equity crowdfunding platforms. Scholars have also examined dynamics on equity crowdfunding platforms (e.g., Hornuf and Schwienbacher, 2018, Vismara, 2018; Vulkan et al., 2016) and outcomes after equity crowdfunding campaigns (e.g., Signori and Vismara, 2018). While all these studies have used samples of firms that are listed on equity crowdfunding platforms, firms do not appear on these platforms at random. Rather, entrepreneurs first need to decide whether they want to seek equity crowdfunding. Therefore, we address the following research question: Which factors influence firms to search for equity crowdfunding and thus list on equity crowdfunding platforms?

Different forms of crowdfunding exist, and most crowdfunding research has focused on reward-based crowdfunding (e.g., Butticè et al., 2017; Chan and Parhankangas, 2017; Colombo et al., 2015; Kuppuswamy and Bayus, 2017; Mollick, 2014). However, contrary to many projects on reward-based crowdfunding platforms, which tend to be artistic and often are not associated with an entrepreneurial firm, projects on equity crowdfunding platforms by definition relate to firms (Cumming et al., 2016). Moreover, the equity crowdfunding context provides a context in which prospective funders of firms are likely primarily driven by financial motives similar to traditional financiers of entrepreneurship (Cholakova and Clarysse, 2015; Cumming and Johan, 2013). Thus, the equity crowdfunding context allows us to extend and bound what is known about raising funds through equity offerings. Practically, equity crowdfunding represents one of 
the fastest-growing components of the crowdfunding market, and policy and regulatory actions have been implemented or are being crafted to support further market growth.

To address our research question, we draw on the pecking order theory (Myers and Majluf, 1984). Although this theory was originally developed in the context of established firms, it is also highly relevant in an entrepreneurial finance context (Cassar, 2004; Cosh et al., 2009). The pecking order theory suggests that because of information asymmetries, entrepreneurs prefer to use internal financing whenever possible; next they will raise external debt financing; and, finally, when their debt capacity is exhausted, they will raise external equity financing, but only as a last resort. Thus, firms are more likely to search for equity crowdfunding, a source of external equity financing, when they lack internal funds and additional debt capacity. To test these claims, we use data on 277 UK firms that are listed on Crowdcube - a major UK equity crowdfunding platform - and 277 matched firms that were not listed on any equity crowdfunding platform. ${ }^{1}$ The findings provide support for our claims.

This study contributes to the crowdfunding literature. Existing crowdfunding studies focus on the factors that explain the funding success of firms that launched an equity crowdfunding campaign, rather than exploring why some firms search for equity crowdfunding and others do not. We evaluate financing decisions before any campaign takes place and provide first-time evidence on the factors that drive entrepreneurial firms to search for equity

\footnotetext{
${ }^{1}$ As we detail subsequently, we use two matched samples. The first sample contains a matched sample based on a random set of UK firms, in which the matched sample is representative of the average entrepreneurial firm in the UK economy with similar characteristics to the sample of firms seeking equity crowdfunding. To construct this sample, we do not select the financing strategy of firms (except that they should not have raised equity crowdfunding). The firms in this first matched sample do not necessarily have a need for external financing. A second sample consists of a matched sample of UK firms that raised debt finance, because debt finance is the most widely used form of external finance by entrepreneurs (e.g., Cosh et al., 2009). The firms in this matched sample thus had a need for external financing. Because our objective is to test the pecking order theory, we do not match with a sample of venture capital financed firms, as both equity crowdfunding and venture capital are external equity finance for which the pecking order theory does not provide a prediction.
} 
crowdfunding. By doing so, we further contribute to the broader entrepreneurial finance literature. While studies have, for example, examined the capital structure of new firms (Cassar, 2004) and also compared firms that raise bank debt with those that raise venture capital (Ueda, 2004), they only focused on the financing obtained (i.e., the intersection between demand and supply). Usually, the firms that searched for equity finance but did not obtain such financing remained unobserved, just like the firms that did not search for external equity (Cumming and Johan, 2017); this is due to the opacity in traditional intermediated financing markets but also implies that these studies are prone to a selection bias (Cosh et al., 2009; Cumming and Johan, 2017). Overall, our study provides unique insights into the demand for external equity and equity crowdfunding in particular.

Moreover, we investigate the position of equity crowdfunding within the pecking order theory. Specifically, in this theory, differences in information sensitivity of different types of funding (i.e., internal funds, debt, and external equity) are of first-order importance and explain entrepreneurs' funding decisions. Therefore, external equity is considered relatively homogeneous regardless of the source from which it is raised. However, equity crowdfunding is different from traditional external equity finance, such as venture capital and angel finance. Equity crowdfunding, for instance, is associated with less stringent contractual terms (Vismara, 2016). Moreover, as with some other forms of crowdfunding, equity crowdfunding relates to different extra-financial services, including market testing and validation, user-based feedback, marketing, and networking (Colombo et al., 2015; Schwienbacher and Larralde, 2012), which could explain why entrepreneurs might prefer equity crowdfunding to traditional bank debt or even internal financing. Thus, there is a possibility that the emergence of equity crowdfunding reverts or distorts the traditional pecking order (Bellavitis et al., 2017). 
The pecking order theory has also received criticism. One point of criticism, as highlighted by Frank and Goyal (2003), is that the theory works well when it should not (i.e., in samples of large firms) but not so well when it should (i.e., in samples of firms with large information asymmetries, such as small firms). A related point of criticism is that the pecking order in an entrepreneurial context may not be due primary to information asymmetries between investors and entrepreneurs but more likely to entrepreneurs' willingness to retain control (Sapienza et al., 2003). Our context, however, is characterized by significant information asymmetries because small crowd investors have fewer resources and incentives to perform detailed due diligence (Ahlers et al., 2015). At the same time, concerns about losing control are

more limited because equity crowdfunding entails giving up smaller equity percentages to a larger and often less coordinated group of investors (compared with venture capital or angel investors). Thus, the equity crowdfunding context provides better insights into the possibility that the information asymmetry mechanism drives the existence of a possible pecking order, thereby disentangling the information asymmetry effect from confounding control issues.

\section{Background literature and hypotheses}

\subsection{Challenges related to traditional external finance and crowdfunding as a potential solution}

Although bank finance is a major source of financing for entrepreneurs (Cosh et al., 2009), popular opinion is that bankers are also hesitant to provide loans to entrepreneurial ventures. This opinion has even strengthened as a consequence of the global financial crisis (Cowling et al., 2012). Bankers care about firm creditworthiness, thus their preference to provide business loans to less informationally opaque firms with an established track record, stable cash flows, and high-quality collateral (Berger and Udell, 1998). Thus, while external debt finance and bank finance, in particular, are often crucial, entrepreneurs also experience problems accessing 
this source of financing, especially when their ventures lack an established track record and invest heavily in intangible assets to pursue future growth (Berger and Udell, 1998; Cassar, 2004; Vanacker and Manigart, 2010). Moreover, because of information asymmetries, some entrepreneurs are discouraged to search for debt financing, despite being creditworthy (Ferrando and Mulier, 2015; Freel et al., 2012; Kon and Storey, 2003).

Entrepreneurs can also search for traditional sources of external equity finance, such as venture capital and angel financing. However, obtaining these sources of financing is often unrealistic for the average entrepreneur (Bhide, 1992). Venture capital and angel investors are primarily interested in ventures with high growth ambitions, and their selection filters are extremely restrictive (Baum and Silverman, 2004; Bertoni et al., 2015; Mason and Harrison, 2004). Puri and Zarutskie (2012) show that only $0.10 \%$ of start-ups in the US receive venture capital financing. Moreover, the difficulty for entrepreneurial ventures to raise traditional equity financing has increased in the aftermath of the financial crisis, as sophisticated investors have become more risk-averse (Block and Sandner, 2009). Finally, even if venture capital or angel financing is available, many entrepreneurs are simply unwilling to search for such financing because of fear of losing control of their ventures (Sapienza et al., 2003). Indeed, venture capital and angel investors often require important equity stakes in ventures and are actively involved in their portfolio firms post-investment (e.g., through involvement on the board of directors), which might be in conflict with the self-determination motive of many entrepreneurs.

More recently, crowdfunding markets have developed to provide entrepreneurs with alternative sources of financing (e.g., Bruton et al., 2015; Fraser et al., 2015), particularly after the financial crisis, which put increased stress on banks (Blaseg and Koetter, 2016). Crowdfunding platforms have implemented different features and structures to reduce information asymmetries, but they also hope to rely on the "wisdom of crowds" to select the most 
promising ventures. The wisdom-of-crowds paradigm argues that the average of crowd guesses is more accurate than the judgment of a sophisticated expert (Surowiecki, 2005). Accordingly, in both the business press and recent academic literature (e.g., Kaufman et al., 2013; Mollick and Robb, 2016), crowdfunding in general and equity crowdfunding in particular have been portrayed as potential routes for entrepreneurs to overcome possible financing constraints.

We draw on the pecking order theory (Myers and Majluf, 1984), which suggests that entrepreneurs will search for equity crowdfunding as a last resort. The pecking order theory, which draws its propositions from the existence of information asymmetries between entrepreneurs and investors, is particularly suitable for this study because the entrepreneurial setting is characterized by high information asymmetry (Cassar, 2004). Moreover, information asymmetry may be even more severe for equity crowdfunding, as small investors have limited incentives and resources to perform detailed screening and due diligence (Ahlers et al., 2015).

\subsection{The pecking order theory and entrepreneurs' search for equity crowdfunding}

The pecking order theory (Myers, 1984; Myers and Majluf, 1984) argues that the cost related to asymmetric information drives financial decision making. As a consequence, entrepreneurs have a preference for internal financing. If that is exhausted or is unavailable, they will next seek external debt financing, and finally they will search for external equity financingincluding equity crowdfunding — as a last resort.

Because the cost of financing increases with information asymmetry, in the pecking order theory (Myers and Majluf, 1984), entrepreneurs will prefer financing new projects or investments with internal funds, which are not subject to information asymmetries (Myers, 1984). However, outside investors are confronted with adverse selection and moral hazard problems, because entrepreneurs have information that outside investors do not have (Akerlof, 1970; Amit et al., 
1998; Stiglitz and Weiss, 1981). When investors are unable to discern "low-quality" firms from "high-quality" firms, they will only be willing to charge an average interest rate (on debt financing) or will only be willing to pay an average price (for a firm's shares). The highestquality firms are unlikely to be attracted by these offers, which may result in a market with "lemons" or lower-quality firms. Outside investors, therefore, require a lemons premium when investing (when information asymmetries become too severe, they may even be unwilling to provide financing altogether). Consequently, information asymmetry often drives a wedge between the costs of internal financing and external debt or equity financing (Carpenter and Petersen, 2002).

Scholars have found support for the idea that entrepreneurs often prefer using cheaper internal funds, whenever available (Cosh et al., 2009; Hanssens et al., 2016; Norton, 1991; Sogorb-Mira, 2005). Michaelas et al. (1999) find that small UK firms make use of internally generated funds as a first resort while those making use of external funds tend to have lower profit levels (or, all else being equal, a lower level of internally generated funds). Vanacker and Manigart (2010) also show that in more profitable, high-growth firms, internally generated funds gradually replace external financing (e.g., external debt, traditional external equity). Thus, entrepreneurial firms with more internal funds prefer financing projects internally. As such, equity crowdfunding, as a relatively new equity financing alternative, would be selected only if internally generated funds are insufficient. Thus:

Hypothesis 1. Entrepreneurial firms with more internally generated funds are less likely to seek equity crowdfunding. 
When internal financing is insufficient to meet entrepreneurial firms' financing requirements, they will be pushed to seek external sources of financing. Existing work has mainly focused on the choice between bank debt and venture capital finance. For example, Ueda (2004) indicates that firms financed through venture capitalists have little collateral and are characterized by high growth potential and high risk. Winton and Yerramilli (2008) provide a model suggesting that venture capital finance (rather than debt finance) is optimal when an entrepreneurial firm's cash flow distribution is risky and positively skewed, with low probability of success, low liquidation value, but high returns if successful. This evidence is broadly in line with the traditional pecking order theory, in that firms raise debt finance when they have additional debt capacity and only move to external equity as a last resort.

Nevertheless, as indicated previously, equity crowdfunding is different from traditional external equity financing, and therefore results from prior empirical research on venture capital are not necessarily generalizable to equity crowdfunding. Moreover, prior research has focused on firms that attracted a particular source of external financing, such as venture capital (e.g., Cumming and Johan, 2017), but often did not consider the firms that unsuccessfully searched for that source of financing or those that never searched for that source of financing. As such, these studies provide only partial insight into entrepreneurs' demand for external financing.

The pecking order theory predicts that when entrepreneurs need external funds, they will first seek debt before they seek equity (Myers and Majluf, 1984) because information asymmetry is smaller between entrepreneurs and debt providers than between entrepreneurs and external equity investors. This is true because under bank debt financing, firms are required to pay fixed interests and repay principal amounts at the maturity date of loans; otherwise, they can be forced into bankruptcy, and banks can still recover (part of) their loans by resorting to the collateral they received. By contrast, outside equity investors become co-owners and therefore may share in the 
uncertain value that gets created in the future. Thus, equity is more information sensitive than debt to the true quality of the entrepreneurial firm.

Empirical research has shown that debt financing_-and bank debt in particular-is an important type of financing for entrepreneurial firms (e.g., Cassar, 2004; Cosh et al., 2009; Robb and Robinson, 2014). However, firms cannot raise debt financing indefinitely. As leverage increases, the probability of financial distress increases, and therefore the marginal cost of debt financing increases rapidly (Carpenter and Petersen 2002). When firms reach sufficiently high debt ratios, debt providers may become unwilling to provide additional funds (even at higher interest rates). Thus, firms with excessive debt levels and related high bankruptcy risks will lack additional debt capacity. These firms may be pushed to seek external equity financing, including equity crowdfunding, as a last resort (e.g., Lemmon and Zender, 2010; Vanacker and Manigart, 2010). In contrast with additional debt financing, additional external equity does not increase the probability of failure (Carpenter and Petersen, 2002). Indeed, firms can, but are not required to, pay dividends to outside equity investors.

The pecking order theory indicates that the costs related to information asymmetry are of first-order importance, which means that entrepreneurs should prefer issuing debt financing first and only raise equity crowdfunding when their debt capacity is exhausted, because they already have excessive levels of debt outstanding. Thus:

Hypothesis 2. Entrepreneurial firms with lower debt capacity (i.e., with excessive debt levels) are more likely to seek equity crowdfunding.

Banks also frequently require collateral, and one of the key reasons firms experience problems accessing (additional) debt financing is the lack of high-quality collateral (Berger and 
Udell, 1998). Tangible assets are generally easier to value and maintain more of their value in case of bankruptcy than intangible assets (Myers, 1984). Thus, firms with more tangible assets tend to have fewer information asymmetry problems. Intangible assets, however, consist mainly of R\&D expenses, patents, and licenses. It is difficult to ascertain the value of intangible assets, and their value may drop considerably in the case of default because they are more likely to be firm specific (Myers, 1984). Thus, firms with more intangible assets tend to have more information asymmetry problems. Overall, firms with more tangible assets are likely to find it easier to attract additional debt financing (Cassar, 2004), while firms with more intangible assets will be pushed to seek external equity financing (Mac an Bhaird and Lucey, 2010; Vanacker and Manigart, 2010), including equity crowdfunding. ${ }^{2}$ Thus:

Hypothesis 3. Entrepreneurial firms with (a) less tangible fixed assets and (b) more intangible fixed assets are more likely to seek equity crowdfunding.

\section{Data and method}

\subsection{Empirical setting: Equity crowdfunding in the UK and Crowdcube}

We chose the equity crowdfunding industry in the UK, the largest and most developed crowdfunding market in Europe, to collect a sufficient number of firms that applied (successfully or not) for equity crowdfunding (e.g., Harrison, 2013; Ralcheva and Roosenboom, 2016; Signori and Vismara, 2018; Vismara, 2016, 2018; Vulkan et al., 2016). In terms of size, the UK accounted for 74\% of the European equity crowdfunding market in 2015 (Statista, 2016a, 2016b). Furthermore, the UK setting provides accounting data on small, privately held firms (Brav,

\footnotetext{
${ }^{2}$ Tangible fixed assets and intangible fixed assets do not sum up to total assets. Firms can also hold financial fixed assets and current assets, including debtors, inventories, and cash.
} 
2009). Finally, by focusing on one country, we minimize unmeasured variance in country-level factors, such as differences in regulatory frameworks (Hornuf and Schwienbacher, 2017).

Although different equity crowdfunding platforms are active in the UK (Estrin et al., 2018; Vismara, 2016), our focus is on Crowdcube, which provides the ideal setting for our research. First, Crowdcube was the first online investment platform to launch in the UK and remains one of the world's largest equity crowdfunding platforms by total amount raised. Up to the end of 2017, firms on Crowdcube have raised $£ 358$ million, and Crowdcube has an investor base of more than 380,000 individuals. Second, Crowdcube has primarily adopted a direct ownership structure, in which individual investors are independently responsible for their shares. Other platforms use alternative structures, such as a nominee structure, in which the platform or its representative is the legal shareholder, holding a seat on the board and managing the investors' interests. Finally, our study provides theoretical and empirical consistency with previous work that also used Crowdcube as an empirical setting (e.g., Cumming et al., 2016; Ralcheva and Roosenboom, 2016; Signori and Vismara, 2018; Vismara 2016, 2018).

Crowdcube uses the traditional "all-or-nothing" model. This model specifies that funds are disbursed to the firm if the crowd's investment reaches or exceeds the target funding goal; if the target funding is not met, money is returned to the investors. Many equity crowdfunding firms offer dual class share structures, in which ordinary shares with single voting rights are coupled with ordinary shares without voting rights or pre-emption rights (Cumming et al., 2016; Signori and Vismara, 2018). The equity offered by firms on Crowdcube is on average 16\% (Ralcheva and Roosenboom, 2016). Entrepreneurs decide on the pricing of the shares and the equity participation offered before launching the campaign. Nonetheless, these aspects can still change if firms lower valuations during the campaign to increase traction or choose to overfund when their campaign has reached $100 \%$ of its funding target. 


\subsection{Data sources and sample}

Our data come from several sources. We first use Crowdcube's website to identify and collect data on the firms that (successfully or not) searched for equity crowdfunding during the 2012-2015 period (inclusive). Then, we used multiple online resources, including the Internet archive Wayback Machine and TechCrunch, to reconstruct the sample of firms that unsuccessfully applied for equity crowdfunding on Crowdcube. ${ }^{3}$ Using additional data sources is important because firms with unsuccessful campaigns are gradually removed from Crowdcube's website.

Disclosure requirements in Europe (including the UK) require privately held firms to publish annual accounting data. We obtained accounting data from the Orbis Europe (previously, Amadeus) database managed by Bureau Van Dijk and Companies House. Orbis Europe contains high-quality accounting data on privately held and publicly traded European firms (Faccio et al., 2011; Vanacker et al., 2017). We use Orbis Europe to identify the matched firms that did not search for equity crowdfunding but share basic characteristics with firms that searched (regardless of their success) for equity crowdfunding. However, the financial statements submitted to Companies House include more information than what Orbis Europe captures, so we use Companies House as our primary data source to subsequently collect accounting data on all firms in our sample.

The sample selection process consisted of several steps. First, we identified firms that sought equity crowdfunding for the first time through Crowdcube between 2012 and 2015. Second, consistent with our focus on equity crowdfunding in entrepreneurial firms, we excluded

\footnotetext{
${ }^{3}$ Wayback Machine enables scholars to capture, manage, and search collections of digital content. In essence, it allows scholars to go back in time and capture historical data from websites.
} 
firms active in real estate. Third, we excluded non-UK firms that applied for equity crowdfunding on Crowdcube. This selection step limits extra-financial reasons for seeking crowdfunding, such as to foster firm internationalization (e.g., Cumming and Johan, 2016; Dai and Siegel, 2017), and further helps reduce cross-country heterogeneity that may stem from reporting requirements and regulations. Finally, we excluded firms that never filed financial statements or did not provide information for the variables of interest. Our final sample includes 277 firms: 134 that successfully raised equity crowdfunding, and 143 that tried to raise equity crowdfunding but were unsuccessful.

Our next step is to form a one-to-one matched sample, matching the firms that searched for equity crowdfunding to similar firms that did not search for equity crowdfunding. To form the matched sample, we start from Orbis Europe, which has data on more than two million UK firms. Similar to other researchers, we use the nearest-neighbor matching algorithm (e.g., Bertoni et al., 2015). ${ }^{4}$ We perform all matching with replacement to reduce possible biases (see Abadie and Imbens, 2012). Accordingly, we matched the 277 firms that searched for equity crowdfunding at the period of getting funding using three a priori defined characteristics: 3-digit industry classification, firm age, and firm size (e.g., Puri and Zarutskie, 2012). If there are multiple matches to the same firm that searched for equity crowdfunding, we select the first one as the matched counterpart. The matching on these basic characteristics makes the accounting data and ratios more comparable between firms.

We consider two one-to-one matched samples (Samples 1 and 2) to show that our results are independent of the matching sample employed. First, we form a matched sample based on a random set of independent firms from the population of UK firms (equivalent to prior work that

\footnotetext{
${ }^{4}$ We also follow the procedure King and Nielsen (2016) suggest and use the coarsened exact matching algorithm as described in the Robustness and post hoc tests section.
} 
compared venture-capital-backed to non-venture-capital-backed firms; e.g., Puri and Zarutskie, 2012). Firms could not have raised or searched for (equity) crowdfunding on other crowdfunding platforms. For this purpose, we (1) checked other prominent UK equity crowdfunding platforms (e.g., Seedrs, Angelsden), (2) verified for any presence on online crowdfunding databases (e.g., Crowdsurfer, Dealroom, Techcrunch), and (3) determined any changes in capital and tapped into the details of the shareholders. On this random set of firms, we performed our matching procedures as described previously. This first matched sample is representative of the average entrepreneurial firm in the economy with similar basic characteristics of the sample of firms seeking equity crowdfunding.

Second, we perform our matching procedures on a sample of firms that raise debt finance (i.e., the most widely used form of external finance by entrepreneurs; see Cosh et al., 2009), because not all the firms in the random sample necessarily need financing. Thus, we form a second matched sample based on a set of firms that made a debt issuance (and thus required external finance). A debt issuance is the net change in total book debt from the period $t-1$ to $t$, normalized by book assets in period $\mathrm{t}-1$, in excess of $5 \%$ (e.g., Brav, 2009; Vanacker and Manigart, 2010). We further employ a minimum threshold of debt issuance that equals the minimum equity financing amount of the sample of firms that searched for equity crowdfunding. We again checked that the matched firms that raised debt financing were not simultaneously listed on crowdfunding platforms.

Table 1 reports the descriptive statistics by industry, age of firms and size (total assets) in Samples 1 and 2. Firms that searched for equity crowdfunding and their matched peers are primarily active in information and communication, wholesale and retail, and manufacturing. The average firm has approximately $£ 200,000$ in total assets and is just over four years old. The results of the paired difference test of the median and mean values confirm the validity of the 
matching process of both one-to-one matched samples. More specifically, the sample of firms that searched for equity crowdfunding does not differ from the matched samples in terms of industry distribution, firm age, or firm size criteria.

\section{[Insert Table 1 about here]}

\subsection{Variables}

To minimize the potential concern that outliers will drive our findings, we winsorize variables that are prone to outliers so that extreme values are converted to the variable's 5th or 95th percentiles (e.g., Cole, 2013). We further minimize concerns about reverse causality by measuring the independent and control variables in the period before firms search for equity crowdfunding (or equivalent period for the matched firms). ${ }^{5}$ Appendix A provides variable definitions. The dependent variable is a dummy variable equal to 1 for firms that searched for equity crowdfunding (successfully or not), and consequently were listed on Crowdcube between 2012 and 2015, and 0 for matched firms that were not listed on a crowdfunding platform.

To test Hypothesis 1, we measure internal funds as accumulated retained profits (or losses) scaled by total assets. All else being equal, firms with more retained profits have more internal funds available (e.g., Chittenden et al., 1996; Michaelas et al., 1999) and thus should be less likely to search for equity crowdfunding.

To test Hypothesis 2, we first measure excessive debt levels (negative equity) as a dummy variable equal to 1 when firms have more debt than total assets (i.e., shareholders' equity is negative) and 0 otherwise (e.g., Vanacker and Manigart, 2010; Vander Bauwhede et al., 2015). There continues to be some debate on what represents an 'excessive' level of debt, at which debt

\footnotetext{
${ }^{5}$ Equivalent period refers to the year before a debt issue in the matched sample based on a set of firms that made a debt issuance and the period in which firms are the same age as their match in the matched sample based on a random set of firms.
} 
providers are unwilling to provide additional debt. Without doubt, firms with negative shareholders' equity will find it very difficult to attract additional debt financing (due to the lack of an equity buffer and the high probability of going bankrupt), while they will need additional equity financing to strengthen their financial position (Vanacker and Manigart, 2010). To show robustness to alternative cutoff rates, we also measure excessive debt levels (>95\%) as a dummy variable equal to 1 when total debt is more than $95 \%$ of total assets and excessive debt levels (>90\%) as a dummy variable equal to 1 when total debt is more than $90 \%$ of total assets. ${ }^{6}$

To test Hypothesis 3, we construct measures that capture the type of fixed assets on the balance sheet. Tangible fixed assets are particularly suitable as collateralizable assets. Thus, firms with more tangible fixed assets (e.g., property, plant and equipment) tend to have higher debt capacity (e.g., Brav, 2009; Cassar, 2004). Following prior research, the tangible fixed assets ratio is measured by the ratio of tangible fixed assets to total assets (Degryse et al., 2012).

Next, we include the variable intangible fixed assets ratio, defined as the ratio of intangible fixed assets to total assets (Degryse et al., 2012). When firms invest more heavily in intangible assets, including $\mathrm{R} \& \mathrm{D}$, patents, trademarks, and brands, they do so to generate future growth; however, these intangible assets are less suitable as collateral and therefore limit debt capacity (Myers, 1984). We also measured the number of patent applications, as an alternative proxy for investments in intangible assets that could also serve as quality signals. However, we omitted this latter variable from the multivariate regressions because it perfectly predicts

\footnotetext{
${ }^{6}$ As we describe subsequently, we control for the continuous long-term debt ratio (bank debt) and short-term debt ratio (bank debt and trade credit). From a pecking order theory perspective, however, firms will only search for external equity financing when they have no additional debt capacity. While the continuous control variables capture the linear effects of long-term and short-term debt on the probability of searching for equity crowdfunding (i.e., where an increase from 0.05 to 0.15 is assumed to be equivalent to an increase from 0.85 to 0.95 ), the independent dummy variable captures a possible shift in behavior when debt levels become 'excessive' and debt providers are unlikely to provide additional financing. An alternative approach to capture non-linear effects is to include both the debt ratios and their squared terms. However, the interpretation of squared terms in logistic and probit regressions models is complex (e.g., Hoetker, 2007).
} 
searching for equity crowdfunding. Specifically, only firms that search for equity crowdfunding had registered patent applications, but the firms in the matched samples did not have any patent applications registered in the PATSTAT database. This worldwide database contains bibliographical and legal status patent data and is maintained by the European Patent Office. Thus, in our multivariate regressions, we focus on the intangible fixed assets ratio.

In addition, we control for a range of variables that might drive firms to search for equity crowdfunding. ${ }^{7}$ Specifically, at the firm level, we control for firm size and firm age. While we employ samples that are matched on firm size (measured as the natural logarithm of total assets plus 1) and firm age (measured as the number of years since formal incorporation), including them as control variables captures any remaining variance related to the traditional financial growth cycle (e.g., Berger and Udell, 1998).

Firms often use multiple sources of outside financing (Cosh et al., 2009), for which we also control. Firms with long-term bank debt outstanding have established lending relationships, which reduces information asymmetry and, as such, provides easier access to additional and cheaper bank debt (Berger and Udell, 1995). Moreover, entrepreneurs in these firms have shown their ability (and willingness) to attract bank debt and, by learning from past financing events, are more likely to search for debt financing again in the future (De Haan and Hinloopen, 2003). We therefore control for long-term debt as the ratio of long-term financial debt to total assets. Firms may also use short-term financial debt, including short-term bank loans and trade credit. Again, these sources of financing reduce the need for other financing, such as equity crowdfunding. We control for short-term debt as the ratio of short-term debt to total assets. We further construct a

\footnotetext{
${ }^{7}$ Given our research focus, we cannot control for all variables (e.g., amount of equity crowdfunding being sought) used in prior research that only had data on firms that searched for equity crowdfunding and examined the success factors on crowdfunding platforms (e.g., Vismara, 2018). Indeed, we focus on what differentiates firms that searched for equity crowdfunding (and were either successful or not) from those firms that did not search for crowdfunding.
} 
variable professional investor, which is a dummy variable equal to 1 when a professional investor (e.g., venture capitalist, angel investor) is a board member and 0 otherwise. We omitted this latter variable from the multivariate regressions because it perfectly predicts searching for equity crowdfunding. Indeed, firms in the matched samples that did not search for equity crowdfunding did not have any professional investors on their boards. This finding confirms how few firms actually attract traditional external equity funds (Cosh et al., 2009).

Firms with operational activities that generate sales and have customers may signal traction to the crowd (e.g., Vismara, 2018). Given that most firms in our sample are small, they report micro-entity or abbreviated accounts. These accounts lack profit-and-loss statements and, thus, sales data. As an alternative proxy to capture whether firms have customers, we construct a dummy variable trade debtors, which equals 1 when firms have customers that owe the firm money and 0 otherwise. ${ }^{8}$ Finally, small firms are also eligible for an audit exemption in the UK (Brav, 2009). While most of the firms in our sample are exempted, they may voluntarily have their financial accounts audited. The presence of an auditor may serve as a quality signal to outsiders and have an effect on the financing knowledge of entrepreneurs through financial consulting/expertise. Therefore, we construct a dummy variable financial auditor, which equals 1 for firms that have an auditor and 0 otherwise.

We further control for team-related variables. We control for the average age of the CEO, a proxy for the level of wealth and human capital of the CEO (Cabral and Mata, 2003). We include a dummy equal to 1 when firms are founder-led and 0 otherwise. Founders are often hesitant to search for traditional external sources of equity financing, such as venture capital or angel investments, because these investors may constrain founders' control of their firms

\footnotetext{
${ }^{8}$ Firms generally give their customers several days (e.g., 45 or 65 days) to pay their bills. Small firms often need to conform to industry practices (Smith and Smith, 2002), and while these practices vary from industry to industry, it is a common complaint that trade debtors take too long to pay in nearly every industry.
} 
(Sapienza et al., 2003). We also include the number of directors. In line with resource dependence theory (Pfeffer and Salancik, 2003), board members may bring substantial human capital and contribute to the financial decision-making process by collecting and exploiting relevant and timely information and knowledge from various stakeholders in and around the firm.

Furthermore, empirical evidence indicates that (professional) social capital plays a role in the success rate of a crowdfunding campaign (e.g., Colombo et al., 2015) and therefore could also influence the search for equity crowdfunding. Proponents also often link their social network profiles to their crowdfunding campaign (e.g., Vismara, 2016). Because network contacts are critical in securing significant pledges the first days of the campaign, having a larger social network helps create momentum that attracts other investors to join. We therefore include LinkedIn connections to proxy for the professional social network. This variable is measured by the average number of connections on the LinkedIn profiles of the board members (divided by 100). We also measure the presence of firms on Twitter. Twitter account is a dummy variable equal to 1 when the firm has a Twitter account and 0 otherwise. Firms with a Twitter account are more likely to have positive attitudes toward social media, which may make them more likely to search for financing on equity crowdfunding platforms. Furthermore, we control for a possible London effect, as $80 \%$ of the UK crowdfunding market is attributed to crowdfunding platforms located in London (Wright et al., 2015). Given the high concentration of equity crowdfunding platforms in London, a larger proportion of firms located in London could be attracted to these platforms in their search for financing. Thus, we include a dummy equal to 1 when the firm's headquarters is located in London and 0 otherwise.

We also control for the possibility that equity crowdfunding is more suitable for firms in particular industries (e.g., Cumming and Johan, 2016) or that the previous success of firms attracts similar firms to equity crowdfunding platforms. For this purpose, we construct a control 
variable industry success rate. We measure this variable as the percentage of firms in a focal firm's industry that successfully raised financing on Crowdcube within the last 12 months. Industry dummies (two-digit) capture any remaining industry effects. Finally, we include year dummies to avoid any general economic trend or event driving our findings. These dummies control for differences in the yearly average cost of financing or differences in the availability of financing sources across years.

\section{Results}

\subsection{Descriptive statistics and multivariate analyses}

Table 2, Panel A, provides descriptive statistics on the firms that searched for equity crowdfunding and a set of matched firms based on a random set of firms (Sample 1). As Panel A shows, firms that searched for equity crowdfunding are more unprofitable than matched firms ( $p$ $<0.01)$. For example, the median firm that searched for equity crowdfunding accumulates losses just larger than its total assets, while the median matched firm accumulates profits that equal $9 \%$ of total assets. This finding provides initial supporting evidence for Hypothesis 1. Furthermore, firms that search for equity crowdfunding are more likely to have excessive debt ratios than matched firms $(p<0.01)$. Some $55 \%$ of firms that searched for equity crowdfunding have negative shareholders' equity compared with $19 \%$ of matched firms. The average firm that searches for equity crowdfunding does not differ from the average matched firm in terms of asset tangibility (16\% vs. 15\%). For the average firm that searches for equity crowdfunding, $11 \%$ of assets are intangible, while this is only $4 \%$ for the average matched firm $(p<0.01)$. Moreover, the average firm that searches for equity crowdfunding has 0.79 patent applications, while none of the firms in the matched sample have patent applications. These findings provide initial supporting evidence for Hypotheses 2 and 3b. Taken together, firms in matched Sample 1 have 
more internal funds available and have more additional debt capacity than firms that searched for equity crowdfunding.

The control variables also provide notable insights. Firms that search for equity crowdfunding have higher long- and short-term debt ratios than matched firms $(p<0.05$ or better). Of note, some $5 \%$ of firms that search for equity crowdfunding have a non-executive director with a venture capitalist or angel investor background, while such directors are not present in the matched firms. We also find a remarkable difference in the trade debtors. While $84 \%$ of firms that searched for equity crowdfunding have customers that owe them money, this is only $69 \%$ in the matched firms $(p<0.01)$. As expected, given that most firms are small, financial accounts are generally not audited; financial accounts are audited for $24 \%$ of firms that searched for equity crowdfunding and $31 \%$ of matched firms $(p<0.05)$. For both the sample of firms that searched for equity crowdfunding and the matched sample, CEOs are in their early 40s on average, and nearly all firms are still founder-led. Firms that search for equity crowdfunding have more directors than matched firms on average ( 2.35 vs. $1.80 ; p<0.01)$, and these directors are also better connected on LinkedIn (2.14 vs. $0.45 ; p<0.01)$. Firms that searched for equity crowdfunding are more likely to be open to social media. Indeed, some $64 \%$ of firms that search for equity crowdfunding have a Twitter account, while this is only $12 \%$ for matched firms. Firms that search for equity crowdfunding are also more likely to be located in London than matched firms $(50 \%$ vs. $15 \% ; p<0.01)$.

\section{[Insert Table 2 about here]}

Table 2, Panel B, reports similar statistics but for firms that searched for equity crowdfunding and matched firms based on a set of firms that raised debt (Sample 2). Insights from Panel B are broadly consistent with those from Panel A. More specifically, firms that searched for equity crowdfunding are more unprofitable than matched firms that raised debt $(p<$ 
0.05 or better). While the median firm that searched for equity crowdfunding accumulates losses just larger than its total assets, the median matched firm accumulates neither profits nor losses. This finding provides initial supporting evidence for Hypothesis 1. While 55\% of firms that searched for equity crowdfunding have negative shareholders' equity, this is slightly lower-but not significantly different-at $49 \%$ for the firms in matched Sample 2. This finding is not surprising, because we conducted a matching on a sample of firms that made an additional debt issuance. However, the firms in matched Sample 2 have more tangible assets and less intangible assets. These findings provide initial supporting evidence for Hypotheses $3 \mathrm{a}$ and $3 \mathrm{~b}$. Also with respect to the control variables, we obtain broadly similar insights from Sample 2.

Appendix B reports correlations between the variables, except for industry and year dummies. The maximum variance inflation factor in all multivariate regressions reported is below 5, which indicates that multicollinearity is not a concern (Neter et al., 1996).

\subsection{Main results}

Table 3 presents multivariate probit regressions and reports marginal effects with robust standard errors. As discussed previously, we use two matched samples. Models 1-4 focus on the matched sample based on a random set of firms (Sample 1), and Models 5-8 focus on the matched sample of firms that made a debt issuance (Sample 2). We first present the baseline models with controls only in Models 1 and 5. We then add the independent variables in Models 2-4 and Models 6-8. We measure excessive debt using three different but related dummy variables. Models 2 and 6 include an excessive debt dummy equal to 1 when equity is negative. Models 3 and 7 include an excessive debt dummy equal to 1 when total debt is larger than $95 \%$ of total assets. Finally, Models 4 and 8 include an excessive debt dummy equal to 1 when total debt is larger than $90 \%$ of total assets. 
[Insert Table 3 about here]

With regard to the control variables, firms with more directors and better-connected directors (with more LinkedIn connections), firms with a Twitter account, firms with customers (trade debtors), and firms located in London have a higher probability of searching for equity crowdfunding. Thus, the factors that drive success on equity crowdfunding platforms (as suggested by prior research) are also the factors that motivate firms to seek a listing on an equity crowdfunding platform.

Models 2-4 and Models 6-8 indicate that firms with more internal funds are less likely to search for equity crowdfunding (all with $p<0.01$ ), consistent with Hypothesis 1 . These findings are not only statistically significant but also economically meaningful. For example, Model 2 shows that an increase from the mean to the mean +1 standard deviation in the firm's internal funds decreases the likelihood that firms search for equity crowdfunding by approximately $21 \%$. Model 6 shows that an increase from the mean to the mean +1 standard deviation in the firm's internal funds decreases the likelihood that firms search for equity crowdfunding by approximately 4\%. Thus, our findings related to Hypothesis 1 hold for a matched sample of firms that did not necessarily have a need for external financing (Sample 1) and those that did have a need for external financing (Sample 2).

Table 3 further shows that firms with excessive debt levels are more likely to search for equity crowdfunding. Model 2 (Model 6) shows that firms with excessive debt levels (i.e., negative shareholders' equity) are approximately 36\% (19\%) more likely to search for equity crowdfunding ( $p<0.05$ or better). We further find evidence that excessive debt levels $(>95 \%)$ and excessive debt levels (>90\%) are positively associated with the search for equity crowdfunding in Sample 1 (all with $p<0.10$ or better). Taking these alternative definitions of the excessive debt level no longer leads to statistically significant results in Sample 2, which might 
not be surprising because we conducted our matching in this case on firms that attracted additional debt financing. Still, taken together, these findings support Hypothesis 2.

In Models 2-4 and 6-8, we fail to find a significant impact of tangible fixed assets on the probability that firms search for equity crowdfunding. Therefore, we fail to find support for Hypothesis 3a. In Models 2-4 and 6-8, we find a positive and significant effect of asset intangibility on the probability of searching for equity crowdfunding (all with $p<0.01$ ). In Model 2 (Model 6), an increase from the mean to the mean +1 standard deviation in the firm's intangible fixed assets ratio increases the likelihood that firms search for equity crowdfunding by approximately $74 \%$ (60\%). Thus, we find support for Hypothesis 3b. Again, our findings related to Hypotheses 2 and $3 \mathrm{~b}$ hold for a matched sample of firms that did not necessarily have a need for external financing (Sample 1) and those that did have a need for external financing (Sample 2).

\subsection{Robustness and post hoc tests}

To assess the robustness of our results, we perform several additional tests. ${ }^{9}$ First, we dropped the variables number of patent applications and professional investor from our multivariate probit regressions because of separation issues (i.e., no firm in the control sample had patent applications or professional investors, including venture capitalists or angels). As an alternative approach, we estimated our models again, including these controls, using the Firth (1993) correction. We find support for the same hypotheses as in our primary results. Unsurprisingly, we also find that firms with patents are also more likely to search for equity crowdfunding than firms in matched Sample 1 (albeit not significant) and Sample $2(p<0.10)$. The finding that number of patent applications is only marginally significant is not surprising, as

\footnotetext{
${ }^{9}$ Detailed results of these tests are not reported here but are available on request.
} 
our variable intangible fixed assets ratio (which captures the book value of patents and other intangible assets) remains positive and significant. Firms with professional investors are also more likely to raise equity crowdfunding than firms in matched Sample $1(p<0.10)$ and Sample $2(p<0.05)$.

Second, we measured the independent variables at time $\mathrm{t}$ or the year of the equity crowdfunding campaign (rather than $\mathrm{t}-1$ or the year before the campaign). We do so to address the concern that not all firms that searched for equity crowdfunding filed their annual accounts before raising equity crowdfunding. Moreover, we used different matching methods, such as coarsened exact matching. Finally, rather than including year dummies, we included the risk-free rate in our multivariate regression model as a control variable for general cost of debt (measured as the monthly average over the year). In all these additional tests, we find further support for our hypotheses; that is, firms that lack internal funds and additional debt capacity are more likely to search for equity crowdfunding.

Third, it is important to consider the possibility that firms with worse characteristics (i.e., no internal funds and no additional debt capacity) may end up doing better. For example, firms with worse characteristics tend to get venture capital, but they tend to do better (e.g., Cole et al., 2016). Puri and Zarutskie (2012) show that cumulative failure rates of venture-capital-backed firms are lower than non-venture-capital-backed firms, with the difference driven largely by lower failure rates in the initial years after receiving venture capital. To assess this possibility in the equity crowdfunding context, we conducted a post hoc test. We also focus on firm failure because failure is a key concern for entrepreneurs and investors in early-stage firms (Damodaran, 2009). We use data from Companies House that reflect the status of all firms in our samples up to the end of November 2017. 
We find that the failure rate of firms that searched for equity crowdfunding is relatively high. Some 30\% of firms that searched for equity crowdfunding between 2012 and 2015 had failed by November 2017 . This percentage is $15 \%$ for firms that raised equity crowdfunding and $43 \%$ for firms that were unsuccessful in raising equity crowdfunding. This finding provides additional evidence that the search for equity crowdfunding tends to be a last resort because firms that are unsuccessful at raising equity crowdfunding subsequently have high failures rates. By contrast, $13 \%$ of firms in the control group from Sample 1 failed, while only $6 \%$ of firms in the control group of Sample 2 failed. The finding that the failure rate of firms that raised equity crowdfunding - and thus received an additional infusion of money - is similar or much higher than the firms in the control groups is also remarkable and at odds with research on venturecapital-backed firms (e.g., Puri and Zarutskie, 2012).

Finally, we show that financial characteristics help explain why some firms seek equity crowdfunding while other firms do not. An immediate follow-up question is whether the same financial characteristics also affect campaign success. To address this question, we performed another post hoc test. Specifically, we estimate a probit model with the dependent variable campaign success, which is a dummy variable equal to 1 if the firm had a successful campaign (i.e., achieved its funding goal) and 0 otherwise. Conditional on searching for equity crowdfunding, we fail to find a significant effect for most financial characteristics on campaign success (a negative effect of tangible fixed assets at $p<0.05$ is a notable exception). This suggests that factors other than historical financial data are more important for equity crowd investors in making investment choices. Equity crowd investors may simply be more concerned about the future and the magnitude of the potential return if things work out.

\section{Discussion}




\subsection{Contributions}

The limited attention by prior research on the factors that drive entrepreneurial firms to search for equity crowdfunding is unfortunate considering that adverse selection issues may be prevalent (e.g., Akerlof and Shiller, 2015). The expanding equity crowdfunding market can provide fertile ground for manipulation and deception (phishing behavior) by taking advantage of the crowds' limited incentives to conduct detailed, pre-investment due diligence and postinvestment monitoring. This possibility means that a better understanding of the characteristics of the firms that list on equity crowdfunding platforms is necessary because only the lowest-quality firms may search for equity crowdfunding. The crowdfunding literature, however, shows that even high-quality firms might search for crowdfunding for multiple reasons, many of them not related to resolving possible financing constraints (e.g., Colombo et al., 2015; da Cruz, 2018; Schwienbacher and Larralde, 2012). This discussion raises some key questions about the role of financial characteristics in searching for equity crowdfunding. Our study provides first-time evidence on how entrepreneurial firms that search for equity crowdfunding differ from those that do not search for equity crowdfunding.

Our evidence is consistent with predictions of the pecking order theory. Specifically, firms with less internal funds - that is, firms with less retained profits (or alternatively more retained losses) - are more likely to search for equity crowdfunding. Moreover, firms with limited additional debt capacity - that is, firms with debt levels that are already excessive and firms with more intangible assets - are more likely to search for equity crowdfunding. The prediction that firms with more tangible assets (an alternative measure of debt capacity) are less likely to seek equity crowdfunding, because they were expected to have access to debt financing, did not receive support. One potential reason is that tangible assets in small firms have little 
collateral value, as those currently available may already be used for securing existing debt, due to these firms' short existence.

Previous work on financing and capital structure decisions in entrepreneurial firms has often focused exclusively on the financing obtained or the intersection between demand and supply for financing (for a similar observation, see Cassar, 2004). By exploiting the crowdfunding context in which firms searched (both successfully and unsuccessfully) for external equity financing, we provide unique insight into the demand for external equity financing. Thus, it is important for future research to control for selection issues or, in other words, take into account that firms self-select to list on an equity crowdfunding platform. While such selection issues have been frequently addressed in the venture capital literature (e.g., Baum and Silverman, 2004), they are largely left unexplored in the crowdfunding literature.

Our study also contributes to the pecking order theory and entrepreneurial finance literature. Scholars (e.g., Bellavitis et al., 2017) have argued that the rise of new sources of financing, such as equity crowdfunding, might disrupt the traditional financial growth cycle (Berger and Udell, 1998), which is based on the pecking order theory. From a pecking order perspective, entrepreneurs raise external equity, such as equity crowdfunding, as a last resort. However, the position of equity crowdfunding within the pecking order theory is theoretically unclear because equity crowdfunding is different from traditional sources of external financing. Indeed, equity crowdfunding could theoretically be a first resort because it brings not only money but also important value-adding services (e.g., visibility, feedback), compared with bank debt. Several scholars also propose that there might be a reversed pecking order, in which entrepreneurs prefer external equity to debt finance, when entrepreneurs are relatively better informed on the assets in place rather than on new growth opportunities (Fulghieri et al., 2014) or when entrepreneurs value investors' skills and value-added services (Garmaise, 2007). While 
traditional external equity investors also bring (different types of) value-added services, a key difference is that firms on equity crowdfunding platforms often provide much smaller equity percentages to a less coordinated and much larger group of small investors, thus retaining more control of their ventures. Despite these challenges for the pecking order theory, our findings are in line with this perspective because equity crowdfunding is considered as a last resort.

Relatedly, in the traditional venture capital or angel investment context, information asymmetry and control issue are often intertwined, and their effects are difficult to disentangle. While the traditional pecking order theory focuses on information asymmetry as the principal mechanism that drives a pecking order, entrepreneurial finance scholars suggest that control issues can actually serve as the principal mechanism (Sapienza et al., 2003). We focus on a context in which information asymmetry is abundant (e.g., Ahlers et al., 2005) but entrepreneurs can raise external equity with a much lower probability of hampering the control of their ventures. While control issues are undeniably important in financial decision making, we find that entrepreneurs also follow pecking order considerations when information asymmetry is high but control issues are less important. In doing so, we show that information asymmetry and related costs likely form a first-order concern for many entrepreneurs.

\subsection{Limitations and avenues for future research}

As with any research, our study is not free of limitations, which may provide important avenues for future research. First, we do not provide theoretical insights or empirical evidence on how entrepreneurs choose between equity crowdfunding and traditional external equity financing. Theoretically, the pecking order theory does not specify how entrepreneurs choose between different sources of external equity finance (equity crowdfunding vs. angel finance vs. venture capital). Practically, for most entrepreneurs, when external funds are required, the most likely 
alternative is debt financing (Cosh et al., 2009). For firms that search for equity crowdfunding, traditional sources of external equity financing may simply not be available because the firms are too young or the amount of financing they need is generally smaller than what traditional investors, and particularly venture capitalists, are willing to provide. Future research that examines these issues will need a different theoretical lens. One approach could be to use control theory and examine how control is actually shared in equity crowdfunded firms. Moreover, do crowd investors (or which types of crowd investors) value more control? Collecting investment documentation of equity crowdfunding campaigns may help answer these questions.

Second, while we provide first-time evidence on firms that searched-successfully or not-for equity crowdfunding and matched firms that did not search for crowdfunding, crowdfunding platforms also perform a selection themselves (e.g., Cumming and Zhang, 2016). This implies that we did not capture all the firms that searched for equity crowdfunding, but only captured those that searched for equity crowdfunding and received approval to list on an equity crowdfunding platform. However, it is important to note that our findings were unlikely driven by this additional selection filter. Indeed, there is no reason equity crowdfunding platforms would prefer to select more unprofitable firms, with limited additional debt capacity. Thus, if anything, the additional selection by equity crowdfunding platforms would weaken our results. Still, heterogeneity in selection and due diligence activities by equity crowdfunding platforms warrant more research attention. In particular, one research avenue would be to investigate the role of platforms in the selection of firms that are allowed to launch a campaign and assess the extent to which platform characteristics affect the ultimate choice of financing by small firms. For example, an increasing number of platforms now pool crowd investors in a financial vehicle as a way to facilitate corporate governance in equity-crowdfunded firms. An open question is whether 
this affects the choice of entrepreneurs within the pecking order theory, given that it leads to different control mechanisms after financing.

Finally, and in line with the previous point, we focus on one specific equity crowdfunding platform in the UK, namely Crowdcube. Future research could test whether our findings are generalizable to other equity crowdfunding platforms and to other countries, which may exhibit other platform structures, due diligence approaches, and contracting mechanisms (e.g., Cumming and Zhang, 2016). However, given that Crowdcube is one of the largest and more reputable equity crowdfunding platforms worldwide, and the UK has a relatively strongly developed equity crowdfunding market, it is unlikely that only Crowdcube would have access to entrepreneurs with limited internal funds and debt capacity while other platforms attract "better" firms. Still, it would be useful to examine how country- and platform-level characteristics (including different regulatory regimes adopted) influence entrepreneurs' search for equity crowdfunding and examine more fully how equity crowdfunding influences firm outcomes in these contexts.

\subsection{Practical implications}

Our study has important implications for policy makers. A key challenge for policy makers is to find the right balance between protecting investors and facilitating access to financing that can reduce entrepreneurs' financial constraints. While the former objective requires more stringent regulation (leading to higher costs for entrepreneurs), the latter calls for less regulation so that transaction costs are reduced. Our results suggest that the pool of firms that search for equity crowdfunding do so as a last resort and thus are very risky. This finding suggests that actions to protect less sophisticated, small investors on equity crowdfunding platforms against hidden information or adverse selection problems would be well taken. Recent regulatory changes have already moved in this direction. For example, New Zealand has 
introduced (tightened) licensing regimes for equity crowdfunding platforms, requiring them to disclose selection criteria and to have adequate disclosure arrangements and question-and-answer forums. Various countries have also introduced investor limitations, to prevent less sophisticated investors from overly investing in any one firm (for an overview of various regulatory changes, see Hornuf and Schwienbacher, 2017). Some countries, such as the US, have also moved to requiring more detail in the documentation, including information about how the funds raised will be used and whether the funds are sufficient to meet the firm's objectives.

The findings are also important for crowd investors with limited means and incentives to perform detailed due diligence and monitoring activities. Investors should be cognizant that while equity crowdfunding might provide prospects for good financial returns in the future, the flip side is that firms on these platforms are high risk in nature. We also find in a post hoc test that financial variables (e.g., profitability) are generally not related to crowdfunding success. With the exception of asset tangibility, other financial variables do not explain the fundraising success on equity crowdfunding platforms. While this finding suggests that the crowd values more forwardlooking variables or future growth rather than backward-looking financial variables, these latter variables might still be worthwhile to consider. Davidsson et al. (2009) illustrate that profitable firms are eventually more likely to reach the desirable state of high growth and high profitability. Still, investors should take great care when entering this market because these investment opportunities are particularly difficult to assess.

Our findings are also important for entrepreneurs considering searching for equity crowdfunding. These entrepreneurs tend to end up in a pool of firms that often try to raise equity crowdfunding as a last resort because they lack internal funds and further debt capacity. Good firms may therefore be pooled with highly financially constrained firms, which in turn may affect the terms they have to offer when running an equity crowdfunding campaign. We find that more 
than $40 \%$ of firms in our sample that unsuccessfully searched for equity crowdfunding have already failed in the meantime; this percentage is 2.9 times higher than for the firms in our sample that successfully raised equity crowdfunding and a staggering 7.2 times higher than firms that raised debt. Thus, failure to achieve funding goals during the equity crowdfunding campaign often threatens the very survival of the firm.

\section{Conclusion}

Through a pecking order theory lens, we investigated the factors that drive firms to list on equity crowdfunding platforms. For this purpose, we used data from 277 firms that searched for equity crowdfunding on Crowdcube - a leading UK equity crowdfunding platform — and two matched samples of firms that did not list on (equity) crowdfunding platforms. We find that firms list on equity crowdfunding platforms as a last resort (i.e., when their internal funds and debt capacity are exhausted). These findings might also explain the relatively high failure rate of firms that unsuccessfully searched for equity crowdfunding. We hope that this study will further stimulate scholars to continue investigating entrepreneurs' demand for equity crowdfunding and its implications for subsequent firm performance and growth.

\section{References}

Abadie, A., \& Imbens, G. (2012). Bias-corrected matching estimators for average treatment effects. Journal of Business \& Economic Statistics, 29(1), 1-11.

Ahlers, G., Cumming, D., Günther, C., \& Schweizer, D. (2015). Signaling in equity crowdfunding. Entrepreneurship Theory and Practice, 39(4), 955-980.

Akerlof, G. (1970). The market for "lemons": Quality uncertainty and the market mechanism. Quarterly Journal of Economics, 84(3), 488-500.

Akerlof, G., \& Shiller, R. (2015). Phishing for phools: The economics of manipulation and deception. Princeton, NJ: Princeton University Press. 
Amit, R., Brander, J., \& Zott, C. (1998). Why do venture capital firms exist? Theory and Canadian evidence. Journal of Business Venturing, 13(6), 441-466.

Baum, J., \& Silverman, B. (2004). Picking winners or building them? Alliance, intellectual, and human capital as selection criteria in venture financing and performance of biotechnology startups. Journal of Business Venturing, 19(3), 411-436.

Beauhurst (2015). The deal: making sense of UK equity investment.

Bellavitis, C., Filatotchev, I., Kamuriwo, D., \& Vanacker, T. (2017). Entrepreneurial finance: new frontiers of research and practice. Venture Capital, 19(1/2), 1-16.

Berger, A., \& Udell, G. (1998). The economics of small business finance: The roles of private equity and debt markets in the financial growth cycle. Journal of Banking \& Finance, 22(6), 613673.

Bertoni, F., Colombo, M., \& Quas, A. (2015). The patterns of venture capital investment in Europe. Small Business Economics, 45(3), 543-560.

Bhide, A. (1992). Bootstrap finance: The art of start-ups. Harvard Business Review, 70(6), 109117.

Blaseg, D., \& Koetter, M. (2016). Crowdfunding and bank stress. In P. Tasca, T. Aste, L. Pelizzon, \& N. Perony (Eds.), Banking beyond banks and money (pp. 17-54). Zurich: Springer International Publishing.

Block, J., \& Sandner, P. (2009). What is the effect of the financial crisis on venture capital financing? Empirical evidence from US Internet start-ups. Venture Capital, 11(4), 295-309.

Brav, O. (2009). Access to capital, capital structure, and the funding of the firm. Journal of Finance, 64(1), 263-308.

Bruton, G., Khavul, S., Siegel, D., \& Wright, M. (2015). New financial alternatives in seeding entrepreneurship: Microfinance, crowdfunding, and peer-to-peer innovations. Entrepreneurship Theory and Practice, 39(1), 9-26.

Butticè, V., Colombo, M., \& Wright, M. (2017). Serial crowdfunding, social capital, and project success. Entrepreneurship Theory and Practice, 41(2), 183-207.

Cabral, L., \& Mata, J. (2003). On the evolution of the firm size distribution: Facts and theory. The American Economic Review, 93(4), 1075-1090.

Carpenter, R., \& Petersen, B. (2002). Capital market imperfections, high-tech investment, and new equity financing. The Economic Journal, 112(477), F54-F72.

Cassar, G. (2004). The financing of business start-ups. Journal of Business Venturing, 19(2), 261283.

Chan, C. S., \& Parhankangas, A. (2017). Crowdfunding innovative ideas: How incremental and radical innovativeness influence funding outcomes. Entrepreneurship Theory and Practice, 41(2), 237-263. 
Chittenden, F., Hall, G., \& Hutchinson, P. (1996). Small firm growth, access to capital markets and financial structure: Review of issues and an empirical investigation. Small Business Economics, 8(1), 59-67.

Cholakova, M., \& Clarysse, B. (2015). Does the possibility to make equity investments in crowdfunding projects crowd out reward-based investments? Entrepreneurship Theory and Practice, 39(1), 145-172.

Cole, R. A. (2013). What do we know about the capital structure of privately held US firms? Evidence from the surveys of small business finance. Financial Management, 42(4), 777-813.

Cole, R., Cumming, D., \& Li, D. (2016). Do banks or VCs spur small firm growth? Journal of International Financial Markets, Institutions and Money, 41, 60-72.

Colombo, M., Franzoni, C., \& Rossi-Lamastra, C. (2015). Internal social capital and the attraction of early contributions in crowdfunding. Entrepreneurship Theory and Practice, 39(1), $75-100$.

Cosh, A., Cumming, D., \& Hughes, A. (2009). Outside entrepreneurial capital. The Economic Journal, 119(540), 1494-1533.

Cowling, M., Liu, W., \& Ledger, A. (2012). Small business financing in the UK before and during the current financial crisis. International Small Business Journal, 30(7), 778-800.

Cumming, D., \& Johan, S. (2013). Demand driven securities regulation: evidence from crowdfunding. Venture Capital: An International Journal of Entrepreneurial Finance, 15, 361379.

Cumming, D., \& Johan, S. (2016). Crowdfunding and entrepreneurial internationalization. In N. Dai, \& D. Siegel (Eds.), Entrepreneurial finance: Managerial and policy implications. London: World Scientific Publishers. Chapter 5.

Cumming, D., \& Johan, S. (2017). The problems with and promise of entrepreneurial finance. Strategic Entrepreneurship Journal, 11(3), 357-370.

Cumming, D., Meoli, M., \& Vismara, S. (2016). Investors' choice between cash and voting rights: evidence from dual-class equity crowdfunding. Working Paper.

Cumming, D., \& Zhang, Y. (2016). Are crowdfunding platforms active and effective intermediaries? Working Paper.

Cumming, D., \& Vismara, S. (2017). De-segmenting research in entrepreneurial finance. Venture Capital, 19(1/2), 17-27.

da Cruz, J. (2018). Beyond financing: Crowdfunding as an informational mechanism. Journal of Business Venturing, forthcoming. https://doi.org/10.1016/j.jbusvent.2018.02.001

Dai, N., \& Siegel, D. (2017). Entrepreneurial finance: managerial and policy implications. London: World Scientific Publishers. 
Damodaran, A. (2009). The dark side of valuation: Valuing young, distressed, and complex businesses. 2nd ed. Upper Saddle River, NJ: FT Press.

Davidsson, P., Steffens, P., \& Fitzsimmons, J. (2009). Growing profitable or growing from profits: Putting the horse in front of the cart? Journal of Business Venturing, 24(4), 388-406.

De Haan, L., \& Hinloopen, J. (2003). Preference hierarchies for internal finance, bank loans, bond, and share issues: Evidence for Dutch firms. Journal of Empirical Finance, 10(5), 661-681.

Degryse H., de Goeij P., \& Kappert P. (2012). The impact of firm and industry characteristics on small firms' capital structure. Small Business Economics, 38(4), 431-447.

Drover, W., Wood. M., \& Zacharakis, A. (2017). Attributes of angel and crowdfunded investments as determinants of VC screening decisions. Entrepreneurship Theory and Practice, 41(3), 323-347.

Estrin, S., Gozman, D., \& Khavul, S. (2018). The evolution and adoption of equity crowdfunding: entrepreneur and investor entry into a new market. Small Business Economics, forthcoming. https://doi.org/10.1007/s11187-018-0009-5

Faccio, M., Marchica, M., \& Mura, R. (2011). Large shareholder diversification and corporate risk-taking. Review of Financial Studies, 24(11), 3601-3641.

Ferrando, A., \& Mulier, K. (2015). The real effects of credit constraints: Evidence from discouraged borrowers in the euro area. ECB Working Paper.

Firth D. (1993). Bias reduction of maximum likelihood estimates. Biometrika, 80(1), 27-38.

Frank, M. Z., \& Goyal, V. K. (2003). Testing the pecking order theory of capital structure. Journal of Financial Economics, 67(2), 217-248.

Fraser, S., Bhaumik, S., \& Wright, M. (2015). What do we know about the relationship between entrepreneurial finance and growth? International Small Business Journal, 33(1), 70-88.

Freel, M., Carter, S., Tagg, S., \& Mason, C. (2012). The latent demand for bank debt: Characterizing “discouraged borrowers.” Small Business Economics, 38(4), 399-418.

Fulghieri, P., Garcia, D., \& Hackbarth, D. (2014). Asymmetric information and the pecking (dis)order. Kenan-Flagler Business School. Working Paper.

Garmaise, M. (2007). Informed investors and the financing of entrepreneurial projects, UCLA Anderson School of Management. Working paper.

Hanssens, J., Deloof, M., \& Vanacker, T. (2016). The evolution of debt policies: New evidence from business startups. Journal of Banking \& Finance, 65, 120-133.

Harrison, R. (2013). Crowdfunding and the revitalisation of the early stage risk capital market: Catalyst or chimera? Venture Capital, 15(4), 283-287.

Hoetker, G. (2007). The use of logit and probit models in strategic management research: Critical issues. Strategic Management Journal, 28(4), 331-343. 
Hornuf, L., \& Schwienbacher, A. (2017). Should securities regulation promote equity crowdfunding? Small Business Economics, 49 (3), 579-593.

Hornuf, L., \& Schwienbacher, A. (2018). Market mechanisms and funding dynamics in equity crowdfunding. Journal of Corporate Finance, forthcoming. https://doi.org/10.1016/j.jcorpfin.2017.08.009

Kaufman, Z., Kassinger, T., \& Traeger, H. L. (2013). Democratizing entrepreneurship: An overview of the past, present, and future of crowdfunding. Bloomberg BNA Securities Regulation \& Law Report, 45(5), 208-217.

King, G., \& Nielsen, R. (2016). Why propensity scores should not be used for matching. Copy at http://j. mp/lsexgVw Download Citation BibTex Tagged XML Download Paper, 378.

Kon, Y., \& Storey, D. (2003). A theory of discouraged borrowers. Small Business Economics, 21(1), 37-49.

Kuppuswamy, V., \& Bayus, B., (2017). Does my contribution to your crowdfunding project matter? Journal of Business Venturing, 32(1), 72-89.

Lemmon, M., \& Zender, J. (2010). Debt capacity and tests of capital structure theories. Journal of Financial and Quantitative Analysis, 45(5), 1161-1187.

Mac an Bhaird, C., \& Lucey, B. (2010). Determinants of capital structure in Irish SMEs. Small Business Economics, 35(3), 357-375.

Mason, C., \& Harrison, R. (2004). Improving access to early stage venture capital in regional economies: a new approach to investment readiness. Local Economy, 19(2), 159-173.

Michaelas, N., Chittenden, F., \& Poutziouris, P. (1999). Financial policy and capital structure choice in UK SMEs: Empirical evidence from company panel data. Small Business Economics, 12(2), 113-130.

Mollick, E. (2014). The dynamics of crowdfunding: An exploratory study. Journal of Business Venturing, 29(1), 1-16.

Mollick, E., \& Robb, A. (2016). Democratizing innovation and capital access. California Management Review, 58(2), 72-87.

Myers, S. (1984). The capital structure puzzle. Journal of Finance, 39(3), 574-592.

Myers, S., \& Majluf, N. (1984). Corporate financing and investment decisions when firms have information that investors do not have. Journal of Financial Economics, 13(2), 187-221.

Neter, J, Kutner H., Nachtsheim C., \& Wasserman W. (1996). Applied linear statistical models. Chicago: Irwin.

Norton, E. (1991). Capital structure and small public firms. Journal of Business Venturing, 6(4), 287-303.

Pfeffer, J., \& Salancik, G. (2003). The external control of organizations: A resource dependence 
perspective. Stanford, CA: Stanford University Press.

Puri, M., \& Zarutskie, R. (2012). On the life cycle dynamics of venture-capital-and non-venture-capital-financed firms. Journal of Finance, 67(6), 2247-2293.

Ralcheva, A., \& Roosenboom, P. (2016). On the road to success in equity crowdfunding. Working paper. Available at SSRN 2727742.

Robb, A., \& Robinson, D. (2014). The capital structure decisions of new firms. Review of Financial Studies, 27(1), 153-179.

Sapienza, H., Korsgaard, M., \& Forbes, D. (2003). The self-determination motive and entrepreneurs' choice of financing. Cognitive approaches to entrepreneurship research, 6, 105138.

Schwienbacher, A., \& Larralde, B. (2012). Crowdfunding of small entrepreneurial ventures. In Cumming, D. (Ed.), The Oxford handbook of entrepreneurial finance (pp. 369-391), New York: Oxford University Press.

Short, J., Ketchen Jr., D., McKenny, A., Allison, T., \& Ireland, R. (2017). Research on crowdfunding: reviewing the (very recent) past and celebrating the present. Entrepreneurship Theory and Practice, 41(2), 149-160.

Signori, A., \& Vismara, S. (2018). Does success bring success? The post-offering lives of equitycrowdfunded firms. Journal of Corporate Finance, forthcoming. https://doi.org/10.1016/j.jcorpfin.2017.10.018

Smith, J.K., \& Smith, R.L. (2002). Entrepreneurial finance. New York: Wiley.

Sogorb-Mira, F. (2005). How SME uniqueness affects capital structure: Evidence from a 19941998 Spanish data panel. Small Business Economics, 25(5), 447-457.

Statista (2016a). Equity-based crowdfunding transaction value in Europe (excluding the UK) from 2012 to 2015, https://www.statista.com/statistics/412460/europe-alternative-financetransactions-value-equity-crowdfunding/.

Statista (2016b). Market value of equity crowdfunding in the UK in 2014 and 2015, https://www.statista.com/statistics/372838/uk-alternative-finance-equity-crowdfunding-market-valuegrowth/.

Stiglitz, J. E., \& Weiss, A. (1981). Credit rationing in markets with imperfect information. The American Economic Review, 71(3), 393-410.

Surowiecki, J. (2005). The wisdom of crowds. New York: Anchor.

Ueda, M. (2004). Banks versus venture capital: Project evaluation, screening, and expropriation. Journal of Finance, 59(2), 601-621.

Vanacker, T., Collewaert, V., \& Zahra, S. A. (2017). Slack resources, firm performance, and the institutional context: Evidence from privately held European firms. Strategic Management Journal, 38(6), 1305-1326. 
Vanacker, T., \& Manigart, S. (2010). Pecking order and debt capacity considerations for highgrowth companies seeking financing. Small Business Economics, 35(1), 53-69.

Vander Bauwhede, H., De Meyere, M., \& Van Cauwenberge, P. (2015). Financial reporting quality and the cost of debt of SMEs. Small Business Economics, 45(1), 149-164.

Vismara, S. (2016). Equity retention and social network theory in equity crowdfunding. Small Business Economics, 46(4), 579-590.

Vismara, S. (2018). Information cascades among investors in equity crowdfunding. Entrepreneurship Theory and Practice, forthcoming. https://doi.org/10.1111/etap.12261

Vulkan, N., Åstebro, T., \& Sierra, M. (2016). Equity crowdfunding: A new phenomena. Journal of Business Venturing Insights, 5, 37-49.

Winton, A., \& Yerramilli, V. (2008). Entrepreneurial finance: Banks versus venture capital. Journal of Financial Economics, 88(1), 51-79.

Wright, M., Hart M. \& Fu K. (2015). A nation of angels. Assessing the impact of angel investing across the UK. Enterprise Research Centre. 


\section{Table 1}

Matched samples.

This table presents the industry distribution (on section level) and the mean (median) values of firm age and size for the matched samples of firms that searched for equity crowdfunding and those that did not list on crowdfunding platforms. All variables are measured at the time of searching for equity financing between 2012 and 2015 (included). We consider two one-to-one matched samples to demonstrate that our results are independent of the matching sample employed. First, we form a matched sample based on a random set of independent firms from the population of UK firms (Sample 1). Second, we perform a matching procedure on a sample of UK firms that raised debt financing at the same period as firms that searched for equity crowdfunding (Sample 2), because all the firms in Sample 1 do not necessarily need financing. Wilcoxon tests and t-tests on the differences between the firms that searched for equity crowdfunding and the matched control group are reported.

\section{Panel A: Sample 1}

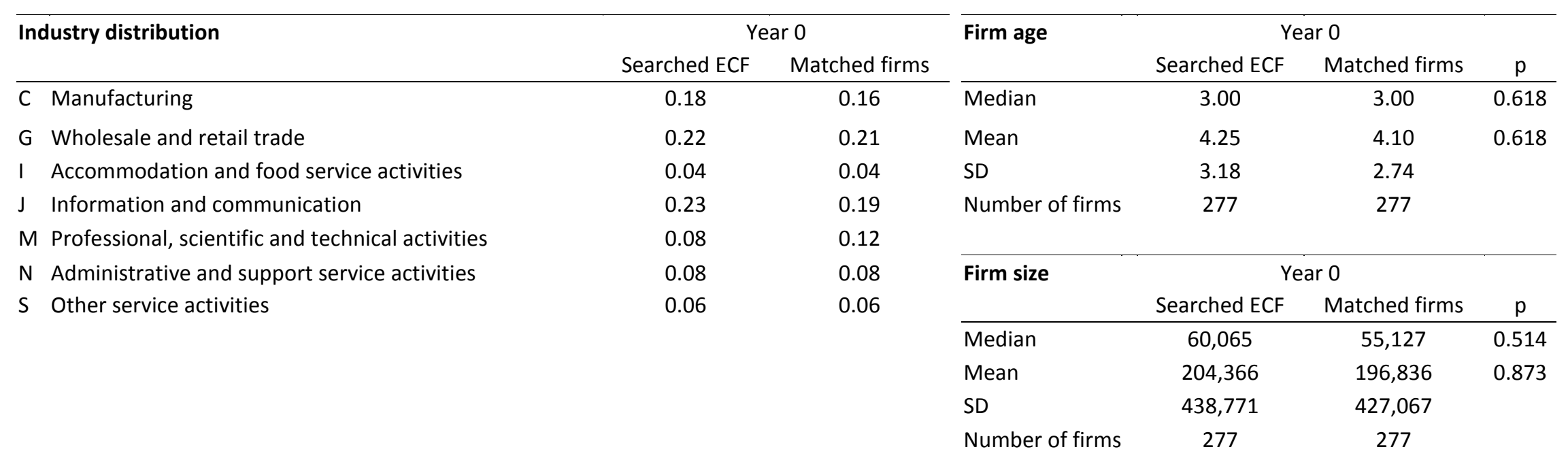


Table 1 - continued

\section{Panel B: Sample 2}

\begin{tabular}{|c|c|c|c|c|c|c|}
\hline Industry distribution & \multicolumn{2}{|c|}{ Year 0} & \multirow[t]{2}{*}{ Firm age } & \multicolumn{2}{|c|}{ Year 0} & \multirow[b]{2}{*}{$\mathrm{p}$} \\
\hline & Searched ECF & Matched firms & & Searched ECF & Matched firms & \\
\hline C Manufacturing & 0.18 & 0.17 & Median & 3.00 & 3.00 & 0.503 \\
\hline G Wholesale and retail trade & 0.22 & 0.22 & Mean & 4.25 & 4.25 & 0.911 \\
\hline I Accommodation and food service activities & 0.04 & 0.04 & SD & 3.18 & 2.61 & \\
\hline J Information and communication & 0.23 & 0.23 & Number of firms & 277 & 277 & \\
\hline M Professional, scientific and technical activities & 0.08 & 0.08 & & & & \\
\hline $\mathrm{N}$ Administrative and support service activities & 0.08 & 0.08 & Firm size & & & \\
\hline \multirow[t]{5}{*}{ S Other service activities } & 0.06 & 0.03 & & Searched ECF & Matched firms & $\mathrm{p}$ \\
\hline & & & Median & 60,065 & 54,377 & 0.544 \\
\hline & & & Mean & 204,366 & 199,983 & 0.975 \\
\hline & & & SD & 438,771 & 448,250 & \\
\hline & & & Number of firms & 277 & 277 & \\
\hline
\end{tabular}




\section{Table 2}

Descriptive statistics.

This table reports the descriptive statistics (number of observations, mean, median, and standard deviation) for both matched samples. Panel A provides the descriptive statistics for the firms that searched for equity crowdfunding and a set of matched firms based on a random set of UK firms (Sample 1). Panel B reports similar statistics but for the firms that searched for equity crowdfunding and matched firms based on a set of UK firms that raised debt in the same year (Sample 2). Wilcoxon tests and t-tests on the differences between the firms that searched for equity crowdfunding and the matched control group are reported. *, $* *$, and $* * *$ represent statistical significance at the $10 \%, 5 \%$, and $1 \%$ levels, respectively.

\begin{tabular}{|c|c|c|c|c|c|c|c|c|c|c|c|c|}
\hline \multirow{2}{*}{$\begin{array}{l}\text { Panel A - Sample } 1 \\
\text { Variable }\end{array}$} & \multicolumn{4}{|c|}{ Searched for ECF (successfully or not) } & \multicolumn{4}{|c|}{ Matched firms (random set of firms) } & \multicolumn{3}{|c|}{ Difference tests } & \\
\hline & $\mathrm{N}$ & Mean & Median & SD & $\mathrm{N}$ & Mean & Median & SD & Mean & & Median & \\
\hline Internal funds & 277 & -2.60 & -1.04 & 3.45 & 277 & -0.04 & 0.09 & 1.27 & 11.51 & $* * *$ & 14.94 & $* * *$ \\
\hline Excessive debt levels (negative equity) & 277 & 0.55 & 1.00 & 0.50 & 277 & 0.19 & 0.00 & 0.40 & -9.34 & $* * *$ & -8.68 & $* * *$ \\
\hline Excessive debt levels (95\%) & 277 & 0.59 & 1.00 & 0.49 & 277 & 0.32 & 0.00 & 0.47 & -6.61 & $* * *$ & -6.37 & $* * *$ \\
\hline Excessive debt levels (90\%) & 277 & 0.61 & 1.00 & 0.49 & 277 & 0.37 & 0.00 & 0.48 & -5.73 & $* * *$ & -5.57 & $* * *$ \\
\hline Tangible fixed assets ratio & 277 & 0.16 & 0.03 & 0.24 & 277 & 0.15 & 0.02 & 0.24 & -0.52 & & -0.80 & \\
\hline Intangible fixed assets ratio & 277 & 0.11 & 0.00 & 0.22 & 277 & 0.04 & 0.00 & 0.13 & -4.21 & $* * *$ & -4.23 & $* * *$ \\
\hline Number of patent applications & 277 & 0.79 & 0.00 & 4.04 & 277 & 0.00 & 0.00 & 0.00 & -3.16 & $* * *$ & -4.99 & $* * *$ \\
\hline Firm size & 277 & 10.23 & 10.72 & 2.84 & 277 & 10.14 & 10.89 & 3.18 & -0.38 & & 0.56 & \\
\hline Firm age & 277 & 3.25 & 2.00 & 3.19 & 277 & 3.11 & 2.00 & 2.75 & -0.58 & & -0.49 & \\
\hline Long-term financial debt ratio & 277 & 0.24 & 0.46 & 0.00 & 277 & 0.12 & 0.00 & 0.31 & -3.69 & $* * *$ & -2.44 & $* *$ \\
\hline Short-term debt ratio & 277 & 1.99 & 0.80 & 2.95 & 277 & 0.70 & 0.56 & 0.89 & -7.09 & $* * *$ & -4.72 & $* * *$ \\
\hline Professional investor & 277 & 0.05 & 0.00 & 0.22 & 277 & 0.00 & 0.00 & 0.00 & -4.02 & $* * *$ & -3.97 & $* * *$ \\
\hline Trade debtors & 277 & 0.84 & 1.00 & 0.37 & 277 & 0.69 & 1.00 & 0.46 & 0.00 & $* * *$ & -3.94 & $* * *$ \\
\hline Financial auditor & 277 & 0.24 & 0.00 & 0.43 & 277 & 0.31 & 0.00 & 0.46 & 1.93 & $* *$ & 1.93 & $* *$ \\
\hline CEO age & 277 & 43.66 & 43.00 & 13.30 & 277 & 42.66 & 50.00 & 11.17 & -0.96 & & -0.55 & \\
\hline Founder-led & 277 & 0.99 & 1.00 & 0.12 & 277 & 0.99 & 0.00 & 0.11 & -0.13 & & -0.13 & \\
\hline Number of directors & 277 & 2.35 & 2.00 & 1.35 & 277 & 1.80 & 2.00 & 0.87 & -5.65 & $* * *$ & -4.89 & $* * *$ \\
\hline LinkedIn connections & 277 & 2.14 & 1.83 & 1.82 & 277 & 0.45 & 0.00 & 1.15 & -12.95 & $* * *$ & -13.39 & $* * *$ \\
\hline Twitter account & 277 & 0.64 & 1.00 & 0.48 & 277 & 0.12 & 0.00 & 0.32 & -14.94 & $* * *$ & -12.61 & $* * *$ \\
\hline London effect & 277 & 0.50 & 1.00 & 0.50 & 277 & 0.15 & 0.00 & 0.36 & -9.56 & $* * *$ & -8.86 & $* * *$ \\
\hline Industry success rate & 277 & 0.38 & 0.27 & 0.30 & 277 & 0.38 & 0.27 & 0.30 & - & & - & \\
\hline
\end{tabular}




\section{Table 2 - continued}

\begin{tabular}{|c|c|c|c|c|c|c|c|c|c|c|c|c|}
\hline \multirow{2}{*}{$\begin{array}{l}\text { Panel B - Sample } 2 \\
\text { Variable }\end{array}$} & \multicolumn{4}{|c|}{ Searched for ECF (successfully or not) } & \multicolumn{4}{|c|}{ Matched firms (received debt financing) } & \multicolumn{4}{|c|}{ Difference tests } \\
\hline & $\mathrm{N}$ & Mean & Median & SD & $\mathrm{N}$ & Mean & Median & SD & Mean & & Median & \\
\hline Internal funds & 277 & -2.60 & -1.04 & 3.45 & 277 & -2.26 & 0.00 & 5.43 & 2.50 & $* *$ & 7.47 & $* * *$ \\
\hline Excessive debt levels (negative equity) & 277 & 0.55 & 1.00 & 0.50 & 277 & 0.49 & 0.00 & 0.50 & -1.37 & & -1.37 & \\
\hline Excessive debt levels (95\%) & 277 & 0.58 & 1.00 & 0.49 & 277 & 0.62 & 1.00 & 0.48 & 1.02 & & 1.02 & \\
\hline Excessive debt levels (90\%) & 277 & 0.60 & 1.00 & 0.49 & 277 & 0.69 & 1.00 & 0.46 & 2.17 & ** & 2.16 & \\
\hline Tangible fixed assets ratio & 277 & 0.16 & 0.03 & 0.24 & 277 & 0.22 & 0.08 & 0.28 & 2.66 & $* * *$ & 2.87 & $* *$ \\
\hline Intangible fixed assets ratio & 277 & 0.11 & 0.00 & 0.22 & 277 & 0.05 & 0.00 & 0.16 & -3.90 & $* * *$ & -4.14 & $* * *$ \\
\hline Number of patent applications & 277 & 0.79 & 0.00 & 4.04 & 277 & 0.00 & 0.00 & 0.00 & -3.38 & $* * *$ & -5.35 & $* * *$ \\
\hline Firm size & 277 & 10.23 & 10.72 & 2.84 & 277 & 10.39 & 10.87 & 2.67 & 0.69 & & 1.00 & \\
\hline Firm age & 277 & 3.25 & 2.00 & 3.19 & 277 & 2.87 & 2.00 & 0.00 & -1.57 & & -1.72 & $*$ \\
\hline Long-term financial debt ratio & 277 & 0.24 & 0.46 & 0.00 & 277 & 1.08 & 0.01 & 2.08 & 4.29 & $* * *$ & 5.30 & $* * *$ \\
\hline Short-term debt ratio & 277 & 1.99 & 0.80 & 2.95 & 277 & 1.24 & 0.66 & 2.16 & -3.49 & $* * *$ & -2.28 & $* *$ \\
\hline Professional investor & 277 & 0.05 & 0.00 & 0.22 & 277 & 0.00 & 0.00 & 0.00 & -4.02 & $* * *$ & -3.97 & $* * *$ \\
\hline Trade debtors & 277 & 0.84 & 1.00 & 0.37 & 277 & 0.74 & 1.00 & 0.44 & -2.85 & $* * *$ & -2.84 & $* * *$ \\
\hline Financial auditor & 277 & 0.24 & 0.00 & 0.43 & 277 & 0.31 & 0.00 & 0.46 & 1.93 & $* *$ & 1.93 & $* *$ \\
\hline CEO age & 277 & 43.66 & 43.00 & 13.30 & 277 & 46.16 & 45.00 & 11.09 & 2.91 & $* * *$ & 2.85 & $* * *$ \\
\hline Founder-led & 277 & 0.99 & 1.00 & 0.12 & 277 & 0.99 & 1.00 & 0.11 & -0.13 & & -0.13 & \\
\hline Number of directors & 277 & 2.35 & 2.00 & 1.35 & 277 & 1.94 & 2.00 & 1.01 & -4.13 & $* * *$ & -3.61 & $* * *$ \\
\hline LinkedIn connections & 277 & 2.14 & 1.83 & 1.82 & 277 & 0.81 & 0.00 & 1.37 & -9.97 & $* * *$ & -10.16 & $* * *$ \\
\hline Twitter account & 277 & 0.64 & 1.00 & 0.48 & 277 & 0.19 & 0.00 & 0.39 & -12.28 & $* * *$ & -10.94 & $* * *$ \\
\hline London effect & 277 & 0.50 & 1.00 & 0.50 & 277 & 0.24 & 0.00 & 0.43 & -6.73 & $* * *$ & -6.48 & $* * *$ \\
\hline Industry success rate & 277 & 0.38 & 0.27 & 0.30 & 277 & 0.38 & 0.27 & 0.30 & - & & - & \\
\hline
\end{tabular}


Table 3

Regression analyses of the probability of searching for equity crowdfunding

This table presents probit regressions using as the dependent variable a dummy variable equal to 1 for firms that searched for equity crowdfunding and 0 otherwise. The independent and control variables were introduced in Table 2 and defined in Appendix A. Models 1-4 focus on the matched sample based on a random set of UK firms (Sample1). Models 5-8 are based on the matched sample of UK firms that raised debt finance (Sample 2). In Models 1 and 5, we present the baseline model with control variables only. We then add different measures of excessive debts in Models 2-4 and Models 6-8. The reported coefficients are marginal effects to show the economic significance. Robust standard errors are reported in brackets below the coefficient values. *, **, and *** represent statistical significance at the $10 \%, 5 \%$, and $1 \%$ levels, respectively.

\begin{tabular}{|c|c|c|c|c|c|c|c|c|}
\hline \multirow[b]{2}{*}{ Dependent variable } & \multicolumn{4}{|c|}{ Sample 1} & \multicolumn{4}{|c|}{ Sample 2} \\
\hline & \multicolumn{4}{|c|}{ Searched for equity crowdfunding } & \multicolumn{4}{|c|}{ Searched for equity crowdfunding } \\
\hline & Model 1 & Model 2 & Model 3 & Model 4 & Model 5 & Model 6 & Model 7 & Model 8 \\
\hline & $\begin{array}{c}\text { Marginal } \\
\text { effect }\end{array}$ & $\begin{array}{c}\text { Marginal } \\
\text { effect }\end{array}$ & $\begin{array}{c}\text { Marginal } \\
\text { effect }\end{array}$ & $\begin{array}{c}\text { Marginal } \\
\text { effect }\end{array}$ & $\begin{array}{c}\text { Marginal } \\
\text { effect }\end{array}$ & $\begin{array}{c}\text { Marginal } \\
\text { effect }\end{array}$ & $\begin{array}{c}\text { Marginal } \\
\text { effect }\end{array}$ & $\begin{array}{c}\text { Marginal } \\
\text { effect }\end{array}$ \\
\hline \multicolumn{9}{|l|}{ Independent variables } \\
\hline Internal funds & & $\begin{array}{c}-0.209 * * * \\
(0.044)\end{array}$ & $\begin{array}{c}-0.200^{* * *} * \\
(0.044)\end{array}$ & $\begin{array}{c}-0.201^{* * *} \\
(0.045)\end{array}$ & & $\begin{array}{c}-0.041 * * * \\
(0.010)\end{array}$ & $\begin{array}{c}-0.036^{* * *} * \\
(0.010)\end{array}$ & $\begin{array}{c}-0.033 * * * \\
(0.010)\end{array}$ \\
\hline Excessive debt levels (negative equity) & & $\begin{array}{c}0.356 * * * \\
(0.098)\end{array}$ & & & & $\begin{array}{c}0.186 * * * \\
(0.065)\end{array}$ & & \\
\hline Excessive debt levels (>95\%) & & & $\begin{array}{c}0.171 * * \\
(0.088)\end{array}$ & & & & $\begin{array}{c}0.052 \\
(0.062)\end{array}$ & \\
\hline Excessive debt levels (>90\%) & & & & $\begin{array}{c}0.158 * \\
(0.087)\end{array}$ & & & & $\begin{array}{c}-0.035 \\
(0.061)\end{array}$ \\
\hline Tangible fixed assets ratio & & $\begin{array}{c}0.187 \\
(0.161)\end{array}$ & $\begin{array}{c}0.214 \\
(0.152)\end{array}$ & $\begin{array}{c}0.209 \\
(0.152)\end{array}$ & & $\begin{array}{c}0.059 \\
(0.103)\end{array}$ & $\begin{array}{c}0.095 \\
(0.101)\end{array}$ & $\begin{array}{c}0.104 \\
(0.102)\end{array}$ \\
\hline Intangible fixed assets ratio & & $\begin{array}{c}0.743 * * * \\
\quad(0.18)\end{array}$ & $\begin{array}{c}0.821 * * * \\
(0.178)\end{array}$ & $\begin{array}{c}0.806 * * * \\
(0.176)\end{array}$ & & $\begin{array}{c}0.598 * * * \\
(0.143)\end{array}$ & $\begin{array}{c}0.586 * * * \\
(0.141)\end{array}$ & $\begin{array}{c}0.587 * * * \\
(0.141)\end{array}$ \\
\hline \multicolumn{9}{|l|}{ Control variables } \\
\hline Firm size & $\begin{array}{l}-0.020 \\
(0.012)\end{array}$ & $\begin{array}{c}-0.021 \\
(0.015)\end{array}$ & $\begin{array}{l}-0.026 * \\
(0.015)\end{array}$ & $\begin{array}{c}-0.029 * * \\
(0.015)\end{array}$ & $\begin{array}{c}-0.029 * * \\
(0.012)\end{array}$ & $\begin{array}{c}-0.033 * * \\
(0.013)\end{array}$ & $\begin{array}{c}-0.034 * * * \\
(0.013)\end{array}$ & $\begin{array}{c}-0.033 * * * \\
(0.013)\end{array}$ \\
\hline Firm age & $\begin{array}{c}0.013 \\
(0.012)\end{array}$ & $\begin{array}{c}0.028 * * \\
(0.013)\end{array}$ & $\begin{array}{c}0.028 * * \\
(0.012)\end{array}$ & $\begin{array}{c}0.027 * * \\
(0.012)\end{array}$ & $\begin{array}{c}0.012 \\
(0.009)\end{array}$ & $\begin{array}{c}0.016^{*} \\
(0.010)\end{array}$ & $\begin{array}{c}0.015 \\
(0.010)\end{array}$ & $\begin{array}{c}0.016^{*} \\
(0.009)\end{array}$ \\
\hline Long-term financial debt ratio & $\begin{array}{c}0.256^{* * * *} \\
(0.090)\end{array}$ & $\begin{array}{c}-0.312 * * \\
(0.122)\end{array}$ & $\begin{array}{c}-0.193 \\
(0.118)\end{array}$ & $\begin{array}{l}-0.184 \\
(0.119)\end{array}$ & $\begin{array}{c}-0.06 * * * \\
(0.016)\end{array}$ & $\begin{array}{c}-0.147 * * * \\
(0.029)\end{array}$ & $\begin{array}{c}-0.123^{* * *} * \\
(0.027)\end{array}$ & $\begin{array}{c}-0.109 * * * \\
(0.027)\end{array}$ \\
\hline Short-term debt ratio & $\begin{array}{c}0.106 * * * \\
(0.023)\end{array}$ & $\begin{array}{c}-0.201 * * * \\
(0.055)\end{array}$ & $\begin{array}{c}-0.147 * * * \\
(0.054)\end{array}$ & $\begin{array}{c}-0.144 * * * \\
(0.055)\end{array}$ & $\begin{array}{c}0.020^{*} \\
(0.011)\end{array}$ & $\begin{array}{c}-0.057 * * * \\
(0.020)\end{array}$ & $\begin{array}{c}-0.037 * * \\
(0.018)\end{array}$ & $\begin{array}{c}-0.026 \\
(0.018)\end{array}$ \\
\hline Financial auditor & $\begin{array}{c}-0.112 \\
(0.075)\end{array}$ & $\begin{array}{c}-0.074 \\
(0.078) \\
\end{array}$ & $\begin{array}{c}-0.089 \\
(0.078)\end{array}$ & $\begin{array}{l}-0.093 \\
(0.080)\end{array}$ & $\begin{array}{l}-0.060 \\
(0.057) \\
\end{array}$ & $\begin{array}{l}-0.059 \\
(0.058) \\
\end{array}$ & $\begin{array}{c}-0.060 \\
(0.058) \\
\end{array}$ & $\begin{array}{c}-0.054 \\
(0.058)\end{array}$ \\
\hline
\end{tabular}


Table 3 - continued

\begin{tabular}{|c|c|c|c|c|c|c|c|c|}
\hline \multirow{3}{*}{ Dependent variable } & \multicolumn{4}{|c|}{ Sample 1} & \multicolumn{4}{|c|}{ Sample 2} \\
\hline & \multicolumn{3}{|c|}{ Searched for equity crowdfunding } & \multirow[b]{2}{*}{$\begin{array}{c}\text { Model } 4 \\
\text { Marginal } \\
\text { effect }\end{array}$} & \multicolumn{3}{|c|}{ Searched for equity crowdfunding } & \multirow[b]{2}{*}{$\begin{array}{c}\text { Model } 8 \\
\text { Marginal } \\
\text { effect }\end{array}$} \\
\hline & $\begin{array}{c}\text { Model } 1 \\
\text { Marginal } \\
\text { effect }\end{array}$ & $\begin{array}{c}\text { Model } 2 \\
\text { Marginal } \\
\text { effect }\end{array}$ & $\begin{array}{c}\text { Model } 3 \\
\text { Marginal } \\
\text { effect }\end{array}$ & & $\begin{array}{c}\text { Model } 5 \\
\text { Marginal } \\
\text { effect }\end{array}$ & $\begin{array}{c}\text { Model } 6 \\
\text { Marginal } \\
\text { effect }\end{array}$ & $\begin{array}{c}\text { Model } 7 \\
\text { Marginal } \\
\text { effect } \\
\end{array}$ & \\
\hline Trade debtors (dummy) & $\begin{array}{c}0.135 \\
(0.083)\end{array}$ & $\begin{array}{l}0.196 * * \\
(0.095)\end{array}$ & $\begin{array}{l}0.219 * * \\
(0.093)\end{array}$ & $\begin{array}{c}0.231 * * \\
(0.093)\end{array}$ & $\begin{array}{c}0.166 * * \\
(0.069)\end{array}$ & $\begin{array}{l}0.187 * * \\
(0.074)\end{array}$ & $\begin{array}{c}0.199 * * * \\
(0.073)\end{array}$ & $\begin{array}{c}0.193 * * * \\
(0.073)\end{array}$ \\
\hline CEO age & $\begin{array}{l}0.006 * * \\
(0.003)\end{array}$ & $\begin{array}{c}0.005 \\
(0.003)\end{array}$ & $\begin{array}{c}0.005 * \\
(0.003)\end{array}$ & $\begin{array}{c}0.005 * \\
(0.003)\end{array}$ & $\begin{array}{c}0.001 \\
(0.002)\end{array}$ & $\begin{array}{c}0.000 \\
(0.002)\end{array}$ & $\begin{array}{c}0.000 \\
(0.002)\end{array}$ & $\begin{array}{c}0.000 \\
(0.002)\end{array}$ \\
\hline Founder led & $\begin{array}{c}0.014 \\
(0.175)\end{array}$ & $\begin{array}{l}-0.044 \\
(0.142)\end{array}$ & $\begin{array}{c}-0.025 \\
(0.148)\end{array}$ & $\begin{array}{c}-0.037 \\
(0.144)\end{array}$ & $\begin{array}{c}0.013 \\
(0.221)\end{array}$ & $\begin{array}{c}-0.022 \\
(0.246)\end{array}$ & $\begin{array}{l}-0.017 \\
(0.238)\end{array}$ & $\begin{array}{c}-0.022 \\
(0.240)\end{array}$ \\
\hline Number of directors & $\begin{array}{c}0.127 * * * \\
(0.026)\end{array}$ & $\begin{array}{l}0.064 * * \\
(0.029)\end{array}$ & $\begin{array}{l}0.070 * * \\
(0.028)\end{array}$ & $\begin{array}{c}0.070 * * \\
(0.028)\end{array}$ & $\begin{array}{c}0.086 * * * \\
(0.025)\end{array}$ & $\begin{array}{c}0.077 * * * \\
(0.027)\end{array}$ & $\begin{array}{c}0.074 * * * \\
(0.025)\end{array}$ & $\begin{array}{c}0.072 * * * \\
(0.025)\end{array}$ \\
\hline LinkedIn connections & $\begin{array}{c}0.161 * * * \\
(0.021)\end{array}$ & $\begin{array}{c}0.168 * * * \\
(0.021)\end{array}$ & $\begin{array}{c}0.169 * * * \\
(0.021)\end{array}$ & $\begin{array}{c}0.170 * * * \\
(0.021)\end{array}$ & $\begin{array}{c}0.102 * * * \\
(0.016)\end{array}$ & $\begin{array}{c}0.112 * * * \\
(0.017)\end{array}$ & $\begin{array}{c}0.112 * * * \\
(0.017)\end{array}$ & $\begin{array}{c}0.111 * * * \\
(0.017)\end{array}$ \\
\hline Twitter account & $\begin{array}{c}0.431 * * * \\
(0.063)\end{array}$ & $\begin{array}{c}0.428 * * * \\
(0.067)\end{array}$ & $\begin{array}{c}0.412 * * * \\
(0.066)\end{array}$ & $\begin{array}{c}0.415 * * * \\
(0.067)\end{array}$ & $\begin{array}{c}0.360 * * * \\
(0.054)\end{array}$ & $\begin{array}{c}0.355 * * * \\
(0.056)\end{array}$ & $\begin{array}{c}0.352 * * * \\
(0.055)\end{array}$ & $\begin{array}{c}0.353 * * * \\
(0.056)\end{array}$ \\
\hline London effect & $\begin{array}{c}0.254 * * * \\
(0.067)\end{array}$ & $\begin{array}{c}0.233 * * * \\
(0.071)\end{array}$ & $\begin{array}{c}0.239 * * * \\
(0.071)\end{array}$ & $\begin{array}{c}0.242 * * * \\
(0.071)\end{array}$ & $\begin{array}{c}0.180 * * * \\
(0.055)\end{array}$ & $\begin{array}{c}0.161 * * * \\
(0.056)\end{array}$ & $\begin{array}{c}0.168 * * * \\
(0.056)\end{array}$ & $\begin{array}{c}0.169 * * * \\
(0.056)\end{array}$ \\
\hline Industry success rate & $\begin{array}{c}0.135 \\
(0.141)\end{array}$ & $\begin{array}{l}0.359 * * \\
(0.154)\end{array}$ & $\begin{array}{l}0.315 * * \\
(0.152)\end{array}$ & $\begin{array}{c}0.314 * * \\
(0.152)\end{array}$ & $\begin{array}{c}0.112 \\
(0.142)\end{array}$ & $\begin{array}{c}0.220 \\
(0.139)\end{array}$ & $\begin{array}{c}0.197 \\
(0.139)\end{array}$ & $\begin{array}{c}0.187 \\
(0.139)\end{array}$ \\
\hline $\begin{array}{l}\text { Year dummies } \\
\text { Industry dummies }\end{array}$ & $\begin{array}{l}\text { yes } \\
\text { yes }\end{array}$ & $\begin{array}{l}\text { yes } \\
\text { yes }\end{array}$ & $\begin{array}{l}\text { yes } \\
\text { yes }\end{array}$ & $\begin{array}{l}\text { yes } \\
\text { yes }\end{array}$ & $\begin{array}{l}\text { yes } \\
\text { yes }\end{array}$ & $\begin{array}{l}\text { yes } \\
\text { yes }\end{array}$ & $\begin{array}{l}\text { yes } \\
\text { ves }\end{array}$ & $\begin{array}{l}\text { yes } \\
\text { ves }\end{array}$ \\
\hline \multicolumn{9}{|l|}{ Model diagnostics } \\
\hline Observations & 554 & 554 & 554 & 554 & 554 & 554 & 554 & 554 \\
\hline Wald chi-squared & $187.64 * * *$ & $217.04 * * *$ & $225.53 * * *$ & $225.18 * * *$ & $188.30 * * *$ & $217.92 * * *$ & $212.83 * * *$ & $209.27 * * *$ \\
\hline $\begin{array}{l}\text { Log-likelihood } \\
\text { Pseudo-R2 }\end{array}$ & $\begin{array}{c}-194.156 \\
0.47\end{array}$ & $\begin{array}{c}-154.526 \\
0.58\end{array}$ & $\begin{array}{c}-159.265 \\
0.57\end{array}$ & $\begin{array}{c}-159.559 \\
0.57\end{array}$ & $\begin{array}{c}-260.262 \\
0.35\end{array}$ & $\begin{array}{c}-241.749 \\
0.40\end{array}$ & $\begin{array}{c}-245.258 \\
0.39\end{array}$ & $\begin{array}{c}-245.431 \\
0.39\end{array}$ \\
\hline
\end{tabular}




\section{Appendix A}

Variable definitions

\begin{tabular}{|c|c|}
\hline Variable & Definition \\
\hline \multicolumn{2}{|l|}{ Dependent variable } \\
\hline Searched for equity crowdfunding & Dummy $=1$ if a firm searched (successfully or not) for equity crowdfunding for the first time ( 0 otherwise) \\
\hline \multicolumn{2}{|l|}{ Independent variables } \\
\hline Internal funds & Ratio of the accumulated retained profits (or losses) to total assets \\
\hline Excessive debt levels (negative & Dummy $=1$ for firms having more debt than total assets \\
\hline Excessive debt levels $(95 \%)$ & Dummy $=1$ for firms having debt-to-total assets ratios above $95 \%$ \\
\hline Excessive debt levels $(90 \%)$ & Dummy $=1$ for firms having debt-to-total assets ratios above $90 \%$ \\
\hline Tangible fixed assets ratio & Ratio of the tangible fixed assets to total assets \\
\hline Intangible fixed assets ratio & Ratio of the intangible fixed assets (including R\&D expenses and the value of patents, trademarks, and brand) to total \\
\hline Number of patent applications & Number of patent applications \\
\hline \multicolumn{2}{|l|}{ Control variables } \\
\hline Firm size & Ln (Total Assets +1$)$ \\
\hline Firm age & Number of years from the founding year \\
\hline Long-term financial debt ratio & Ratio of the long-term financial debt to total assets \\
\hline Short-term debt ratio & Ratio of the short-term debt to total assets \\
\hline Professional investor & Dummy $=1$ for firms having a non-executive director with a venture capital or business angel background \\
\hline Trade debtors & Dummy $=1$ for firms having trade debtors (customers who owe the firm money) \\
\hline Financial auditor & Dummy $=1$ for firms having a financial auditor \\
\hline CEO age & Age of the CEO \\
\hline Founder-led & Dummy $=1$ for founder-led firms \\
\hline Number of directors & Number of directors in the board \\
\hline LinkedIn connections & Average number of directors' LinkedIn connections /100 \\
\hline Twitter account & Dummy = 1 for firms having a Twitter account \\
\hline London effect & Dummy $=1$ for firms where the headquarter is located in London \\
\hline Industry success rate & Percentage of firms that successfully searched for equity crowdfunding in an industry on Crowdcube in the year before \\
\hline
\end{tabular}




\section{Appendix B}

Correlations matrix of the key variables and control variables used in Table 3 (Models 1 to 4; Matched Sample 1).

\begin{tabular}{|c|c|c|c|c|c|c|c|c|c|c|c|}
\hline & & $(1)$ & $(2)$ & (3) & $(4)$ & $(5)$ & $(6)$ & $(7)$ & $(8)$ & $(9)$ & $(10)$ \\
\hline (1) & Searched for equity crowdfunding & 1 & & & & & & & & & \\
\hline (2) & Internal funds & $-0.4412 *$ & 1 & & & & & & & & \\
\hline (3) & Excessive debt level (negative equity) & $0.3703 *$ & $-0.5010 *$ & 1 & & & & & & & \\
\hline (4) & Excessive debt level (95\%) & $0.2683 *$ & $-0.3703 *$ & $0.9357 *$ & 1 & & & & & & \\
\hline$(5)$ & Excessive debt level (90\%) & $0.2343^{*}$ & $-0.3488 *$ & $0.9013 *$ & $0.9632 *$ & 1 & & & & & \\
\hline (6) & Tangible fixed assets ratio & 0.0223 & -0.0029 & $0.1764 *$ & $0.1196^{*}$ & $0.1184 *$ & 1 & & & & \\
\hline (7) & Intangible fixed assets ratio & $0.1770 *$ & 0.0742 & 0.0624 & -0.0909 & -0.0668 & $-0.1284 *$ & 1 & & & \\
\hline (8) & Firm size & 0.0162 & $0.1880 *$ & -0.0377 & -0.0901 & -0.0683 & $0.1663 *$ & $0.1984 *$ & 1 & & \\
\hline (9) & Firm age & 0.0249 & 0.0321 & -0.0048 & -0.0158 & -0.0026 & 0.0276 & -0.0585 & $0.1841^{*}$ & 1 & \\
\hline (10) & Long-term financial debt ratio & $0.1556^{*}$ & $-0.2185^{*}$ & $0.3790^{*}$ & $0.3258^{*}$ & $0.3294 *$ & $0.2086^{*}$ & 0.0571 & $0.1070^{*}$ & 0.0565 & 1 \\
\hline (11) & Short-term debt ratio & $0.2896^{*}$ & $-0.7408 *$ & $0.5780 *$ & $0.5451 *$ & $0.5312 *$ & 0.0504 & -0.0678 & $-0.1720 *$ & -0.0118 & -0.0680 \\
\hline (12) & Financial auditor & -0.0508 & 0.0366 & -0.0620 & -0.0889 & -0.0828 & -0.0417 & -0.0621 & $0.1664 *$ & $0.2214^{*}$ & 0.0034 \\
\hline (13) & Trade debtors & $0.1682 *$ & -0.0398 & 0.0709 & 0.005 & -0.0187 & -0.0013 & 0.0387 & $0.5245^{*}$ & $0.1287^{*}$ & 0.0031 \\
\hline (14) & CEO age & 0.0409 & $-0.0946^{*}$ & 0.0615 & 0.0743 & 0.0719 & -0.0611 & 0.0431 & 0.0294 & $0.2802^{*}$ & 0.0777 \\
\hline (15) & Founder led & $0.2018^{*}$ & $-0.1878 *$ & 0.0651 & 0.0029 & 0.0255 & -0.0274 & 0.0273 & -0.0333 & 0.0621 & $0.0915^{*}$ \\
\hline (16) & Number of directors & $0.2348 *$ & $-0.1829 *$ & 0.0796 & -0.0873 & -0.0865 & 0.0417 & 0.0542 & $0.2535^{*}$ & $0.1490 *$ & $0.0882 *$ \\
\hline (17) & LinkedIn connections & $0.4842 *$ & $-0.1610^{*}$ & $0.1213^{*}$ & -0.0875 & -0.109 & -0.0462 & 0.0347 & 0.0048 & -0.0500 & 0.0345 \\
\hline (18) & Twitter account & $0.5377 *$ & $-0.2890 *$ & $0.2216^{*}$ & 0.0663 & 0.0330 & 0.0454 & $0.0846^{*}$ & 0.0249 & -0.0559 & $0.1170^{*}$ \\
\hline (19) & London effect & $0.3780^{*}$ & $-0.1928^{*}$ & $0.1203^{*}$ & -0.0894 & -0.0977 & 0.0484 & 0.0055 & 0.0691 & -0.0291 & 0.0519 \\
\hline (20) & Industry success rate & 0.0056 & 0.0294 & -0.0348 & -0.0372 & -0.0644 & 0.0669 & 0.0461 & $0.1683^{*}$ & 0.0637 & 0.0459 \\
\hline
\end{tabular}

\begin{tabular}{|c|c|c|c|c|c|c|c|c|c|c|}
\hline & & $(11)$ & $(12)$ & $(13)$ & $(14)$ & $(15)$ & $(16)$ & $(17)$ & $(18)$ & $(19)$ \\
\hline (11) & Short-term debt ratio & 1 & & & & & & & & \\
\hline (12) & Financial auditor & -0.0435 & 1 & & & & & & & \\
\hline (13) & Trade debtors & 0.0680 & $0.1079 *$ & 1 & & & & & & \\
\hline (14) & CEO age & 0.0481 & 0.0624 & 0.0157 & 1 & & & & & \\
\hline (15) & Founder led & $0.1103^{*}$ & $-0.1100 *$ & -0.0074 & 0.0330 & 1 & & & & \\
\hline (16) & Number of directors & 0.0245 & $0.0926^{*}$ & $0.1528^{*}$ & $0.1126^{*}$ & $0.1450^{*}$ & 1 & & & \\
\hline (17) & LinkedIn connections & $0.1187^{*}$ & 0.0341 & 0.0814 & $-0.0967 *$ & 0.0041 & -0.0567 & 1 & & \\
\hline (18) & Twitter account & $0.2008^{*}$ & -0.0770 & $0.1653 *$ & -0.0627 & $0.1102 *$ & $0.1814 *$ & $0.3652 *$ & 1 & \\
\hline (19) & London effect & $0.1043^{*}$ & -0.0117 & $0.0927 *$ & $-0.1441 *$ & 0.0577 & $0.1778 *$ & $0.2516^{*}$ & $0.3357 *$ & 1 \\
\hline (20) & Industry success rate & -0.0361 & 0.0456 & $0.0937 *$ & -0.0419 & -0.0758 & 0.0625 & 0.0601 & 0.0458 & 0.0524 \\
\hline
\end{tabular}

$$
\begin{aligned}
& \mathrm{N}=554 \\
& * \mathrm{p}<0.05
\end{aligned}
$$




\section{Appendix B - continued}

Correlations matrix of the key variables and control variables used in Table 3 (Models 5 to 8; Matched Sample 2).

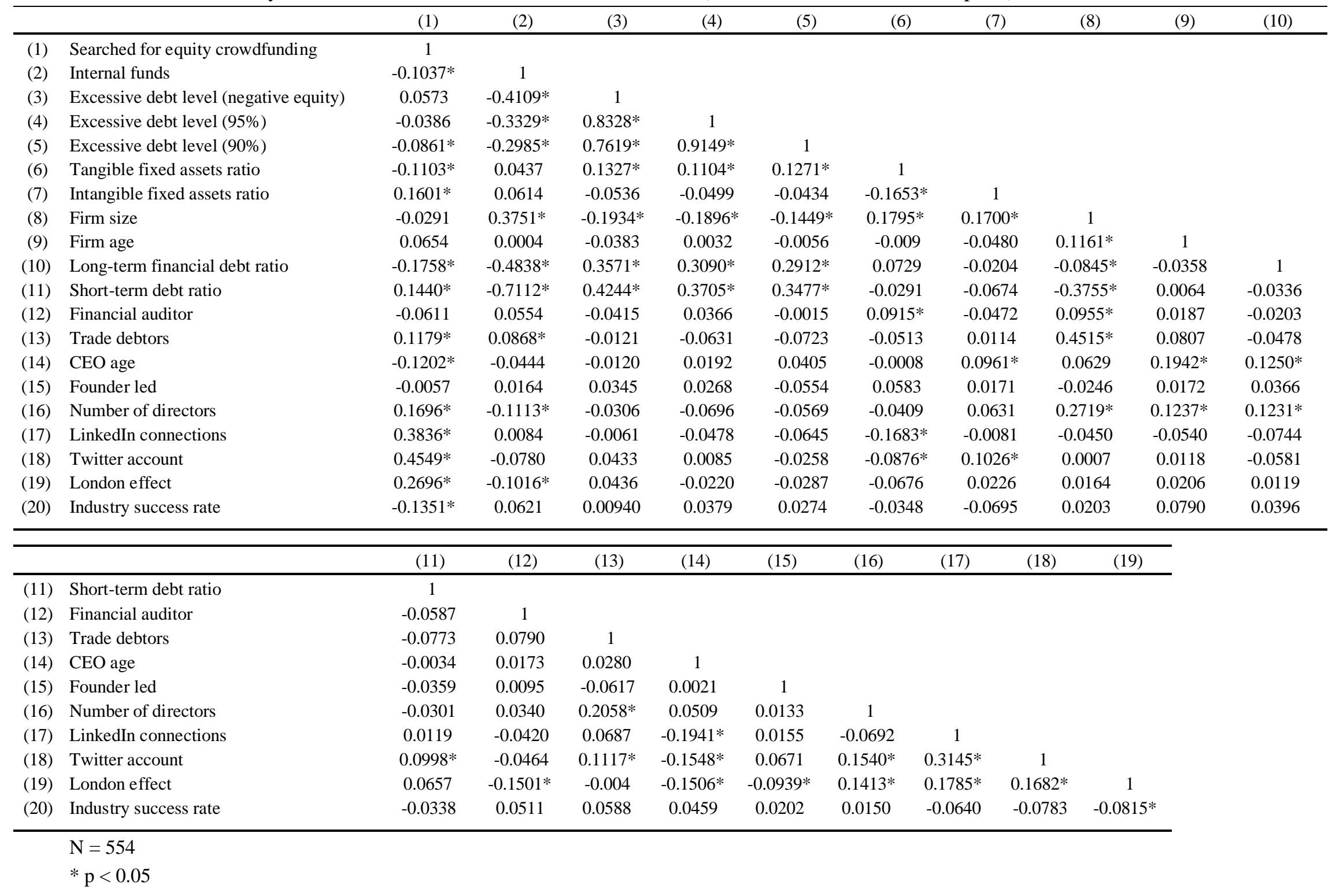

